\title{
RECENT BRYOLOGICAL LITERATURE OF CIS AND BALTIC COUNTRIES. V.
}

\section{НОВАЯ БРИОЛОГИЧЕСКАЯ ЛИТЕРАТУРА ПО СНГ И СТРАНАМ БАЛТИИ. V.}

\author{
CZERnYADJEVA, I. V. ${ }^{1}$ \& M. S. IGNATOV ${ }^{2}$ \\ ЧЕРНЯДЬЕВА, И. В. ${ }^{1}$, М. С. ИГНАТОВ ${ }^{2}$
}

We continue to publish recent bibliography of bryological literature, which either were published by authors of CIS and Baltic countries, or deal with floristic and taxonomic investigations in this territory. In the present paper there cited publications which appeared mostly in 2001-2002. Brief abstracts from conferences are mostly not included.

Proceedings of 3 conferences are abbreviated as follow (here marked in boldface):

Мы продолжаем публикацию библиографии новых бриологических работ, которые либо были опубликованы авторами из стран СНГ и Балтии, либо посвящены флористическим и таксономическим исследованиям на территории этих государств. В данный выпуск включены работы, вышедшие в основном в 2001-2002 гг. (тезисы конференций б. ч. не приводятся).

Материалы екух конференций сокращаются следующим образом (здесь - жирным):

В кн.: Проблемы бриологии на рубеже веков. Материаль межд. совещания, посвященного 90-летию со дня рождения Р.Н. Шлякова (20.06.1912) и И.И. Абрамова (14.07.1912), Санкт-Петербург, 4-6 ноября 2002 г. [In: Problems of bryology at the boundary of centries. Proceedings of the international conference devoted to 90-th anniversary of R..N. Schljakov (20.06.1912) and I.I. Abramov (14.07.1912), Saint Petersburg, November 4-6, 2002]: - "[90-летue]"

В кн.: Ботанические исследования в азиатской России. Мат. ХІ съезда Русского ботанического общества (18-22 августа 2003 г., Новосибирск-Барнаул). Барнаул [In: Botanicheskie issledovaniya v aziatskoj Rossii. Materialy XI s'ezda Russkogo botanicheskogo obshchestva (18-22 August 2003, Novosibirsk-Barnaul) Barbaul]: - “[ХI cъезд РБО]”

В кн.: Проблемы сохранения биоразнообразия в наземных и морских экосистемах севера. Тез. док. международной конф. и выездной сессии Отделения общей биологии РАН, 27-31 августа 2001 г., Anатиты [In: Problems of biodiversity preservation in ground and marine ecosysrems in the north. Abstracts International conference and guest session of the department of the general biology of the Russian Academy of Sciences, 26-31 August, Apatity]: - "Anamumb-2001".

ÂBOLINA, A. 2001. Bryoflora of Latvian National Parks. - 4th European Conference on the Concervation of Bryophytes. Pruhonice, Czech Republic, 1 July-2July 2001. Pruhonice: 12 / The bryoflora includes 322 species. Some species are cited.

ÂBOLINA, A., S. JERMANBNE \& M. LAIVITP 2001. Postdrainage dynamics of the ground vegetation in a transitional mire. - Baltic forestry 7(1): 19-28.

ÂBOLINA, A. 2001. Latvijas sűnu saraksts. - [List of bryophytes of Latvia] Latvijas vegetâcija. 3: 47-87. /The list includes 512 species.

ÂBOLINA, A. \& B. BAMBE. 2001. Sűnu flora dabas liegumâ «Čortoka ezers ar apkârtçjo ainavu».- [Bryoflora in "The Čortoka Lake and its surrounding landscape" Nature Reserve] Latvijas Veěetâcija. 4:105-114. / The list includes 87 species.

[ABRAMOVA, L. I., T. YU. TOLPYSHEVA \& YU. I. ZUEVA] АБРАМОВА, Л.И., Т. Ю. ТОЛПЫШЕВА, Ю. В. ЗУЕВА 2002. К экологии произрастания эпигейных мхов и широколопастных ризоидальных лишай- ников на побережье Кандалакшского залива. - [On the ecology of epigeious mosses and rhizoidal lichens with broad lobes on the Kandalaksha Bay coast] Вестн. Моск. Унив., сер. 16, биол. [Vestn. Mosk. Univ., Ser. 16 Biologiya] [2002](1): 45-52.

[ABRAMOVA, L.I. \& V.A. BAKALIN] АБРАМОВА, Л.И., В.А. БАКАЛИН 2002. О флоре печеночников Зейского заповедника (Амурская область). - [On the flora of Hepaticae of Zeya Reserve (Amur Province, Far East) Бюл. Моск. О-ва Испыт. Прир. Отд. биол. [Bull. Mosk. Obshch. isp. prir. Otd. Biol.] 107(2): 65-67. /50 species are listed.

[AFONINA, O.M., E.N. ANDREEVA, L.E. KURBATOVA \& A.D. POTEMКIN] АФОНИНА, О.М., Е.Н. АНДРЕЕВА, Л.Е. КУРБАТОВА, А.Д. ПОТЕМКИН 2000. Мохообразные (Bryophyta). - [Bryophyta] $B$ кн.: Красная книга природы Ленинградской области. Растения и грибы. СПб. Т. 2 [In: Red data book of Leningrad region. Plants and Fungi. Sankt-Petersburg. V. 2]: 295-358.

1 - Komarov' Botanical Institute of Russian Academy of Sciences, Popova 2, St.-Petersburg 197376 Russia - CaнктПетербург 197376 Попова 2, Ботанический институт РАН

2 - Main Botanical Garden of Russian Academy of Sciences, Botanicheskaya 4, Moscow 127276 Russia - Россия 127276 Москва, Ботаническая 4, Главный ботанический сад Российской Академии Наук 
[AFONINA, O.M.] АФОНИНА, О.М. 2001. Зональное распределение мхов в тундрах Чукотки и Архипелага Северная Земля. - [Zonal distribution of mosses in tundras of Chukotka and Archipelago Severnaya Zemlya] "Anamumb-2001": 7-8.

[AFONINA, O.M.] АФОНИНА, О.М. 2002. Дополнения к флоре мхов архипелага Северная Земля. - [Additions to the moss flora of Severnaya Zenlya Archipelago] Hовости сист. низи. pacm. [Novosti Sist. Nizch. Rast.] 36: 203-210. The annotated list includes 45 species.

[AFONINA, O.M.] АФОНИНА, О.М. 2002. Научный вклад И.И. Абрамова в развитие отечественной бриологии. - [Scientific contribution of I. I. Abramov to homeland bryology] "[90-летие]": 7-13.

[AFONINA, O.M. \& N.V. MATVEEVA] АФОНИНА, O.М., Н.В. МATBEEBA. 2002. Особенности флоры мхов полярных пустынь на примере острова Большевик (Архипелаг Северная Земля). - [Peculiarities of moss flora of arctic deserts with example of Bolshevik Island (Severnaya Zemlya Archi pelago)] "[90-летие]": 15-17.

[AKATOVA, T. V. \& N. B. ESKIN] AKATOBA, T. В., Н. Б. ЕСКИН 2002. Видовое богатство мохово-лишайниковых группировок альпийских низкотравных лугов и лишайниковых пустошей Западного Кавказа. - [Moss and lichen species richness in alpine low-grass meadows and lichen heaths of Western Caucasus] Труды Кавказск. зап. [Trudy Kavkazsk. Zapov.] 16: 29-38.

[AKATOV, V. V., T. B. AKATOVA \& N. B. ESKIN] AKAТОВ, В. В., Т. В. АКАТОВА, Н. Б. ЕСКИН 2003. Состав и видовое богатство растительных сообществ высокогорных лугов и пустошей Кавказского заповедника и сопредельных территорий. - [Species composition and richness of high mountain meadows and heaths of Caucasian Reserve] Труды Кавказск. зап. [Trudy Kavkazsk. Zapov.] 17: 216-239.

[AKATOVA, Т. V.] АКАТОВА, Т. В. 2003 '2002'. Листостебельные мхи Кавказского заповедника (Западный Кавказ, Россия). - [Moss flora of the Caucasian Nature Reserve (Western Caucasus, Russia)] Arctoa 11: 179-204.

[ANDREEVA, E.N.] АНДРЕEBA, Е.H. 2001. Мохообразные (Bryophyta). - [Bryophyta] Tp. СПб O-ва естеcmвoucnom. Cep. 6 [Trudy Sankt-Peterburng.Obshch. Estestvoispyt. Seria 6] 4: 53-66. / Annoteded list of 52 liverworts and 157 mosses (Pskov Province).

[ANDREEVA, E.N.] АНДРEEBA, E.H. 2001. Редкие и нуждающиеся в охране мохообразные. - [Rare and endangered bryophytes of the Sebezhsky National Park] Биоразнообразие и редкие виды национального парка "Себежский". Тр. СПб О-ва естествоиспытателей. Cep. 6 [Bioraznoobrazie i redkie vidy nacionalnogo parka "Sebezhskij. Trudy Sankt-Peterburzhskogo Obshchestva estestvoispytatelej prirody. Ser. 6] 4: 235-236.

[ANDREEVA, E.N. \& E.O. KUZMINA] АНДРЕЕВA, Е.Н., Е.О. КУЗЬМИНА. 2001. Роль Ремдовского заказника в сохранении биоразнообразия сфагновых мхов Псковской области. - [Role of Remdovsky Reserve in protection of biodiversity of peat mosses of Pskov Region] В кн.: Северо-Запад России: взаимодействие общества и природы. Мат. обществ.-научн. конф. с международным участием. Псков, 29-30 ноября 20012.Ч. 2. Псков [In: Severo-zapad Rossii: vzaimodejstvie obshchestva i prirody. Materialy ronferencii. Pskov, 2930 November 2001, Ch. 2]: 92-95. / List of 30 species of Sphagnum, with their dstribution in Pskov Province.

[ANDREEVA, E.N.] АНДРЕEBA, E.H. 2002. Особенности распространения печеночных мхов Вологодской области. - [Features of distribution of liverworts of the Vologda range] "[90-летие]": 13-15.

[ANDREEVA, E.N.] АНДРEEBA, Е.Н. 2002. Мхи Ремдовского заказника. - [Bryophytes of Remdovsky Reserve] Природа Псоквкого края. N 14. СПб [Priroda Pskovskogo Kraya, N 14. Sankt-Petersburg]: 7-12. / List of 27 liverworts and 87 mosses (Pskov Province).

[ANDREEVA, E.N.] АНДРЕEBA, E.H. 2002. Охраняемые виды мохообразных Беларуси и сопредельных территорий. - [Protected bryophytes of Belorussia and surrounding territories] В кн.: Красная книга республики Беларусь: состояние, проблемы, перспективы. Мат. республиканской науч. конф. 12-13 декабря 2002 г. Витебск. [In: Krasnaya kniga respubliki Belarus': sostoyanie, problemy, perspektivy. Materialy konferencii. 12-13 Desember 2002, Vitebsk]: 37-38./15 species are cited.

[ANDREEVA, E.N.] АНДРЕEBA, E.Н. 2002. Использование мхов для индикации характеристик местообитания. [Using of mosses for sites indication] В кн.: Методы изучения лесных сообществ (ред. Ярмишко, В.Т., И.В. Лянгузова) СПб [In: Yarmishko, V.T. \& I.V. Lyangusova. Methods for forest community study. Sankt-Petersburg]:170180. 22 mosses are discussed and illustrated.

[ANTIPIN, V.K. \& M.A. BOYCHUK] АНТИПИН, В.К., M.А. БОЙЧУК 2003. Сфагновые сообщества с Molinia caerulea (Роасеае) на Онежско-Печорских аапа болотах. - [Sphagnum communities with Molinia caerulea (Poaceae) on Onezhsko-Pechorskih aapa-mire] " $[X I$ съезд РБО]": 197.

[BABENKO, L. A., V. V. FEDYAEVA] БАБЕНКО, Л. А., В. В. ФЕЛЯЕВА 2001. Биоразнообразие нижнего Дона: бриофлора. - [Biodiversity of Lower Don River: bryoflora] Ростов-на-Дону, Ростосвкий гос. ун-т [Rostov-na-Done, Rostovsk. Gos. Univ.], $103 \mathrm{pp}$.

[BAISHEVA, E.Z.] БАИШЕВА, Э.3. 2002. Дополнение к бриофлоре Башкирии (Южный Урал) - [Additions to the moss flora of Bashkiria (South Ural)] Hовости сист. низи. pacm. [Novosti Sist. Nizch. Rast.] 36: 210-212. 31 species new for Bashkiria.

[BAKALIN, V.A., N.A. KONSTANTINOVA \& G.V. ZHELEZNOVA] БАКАЛИН, В.А., Н.А. КОНСТАНТИНОВА, Г.В. ЖЕЛЕЗНОВА. 2001. К флоре печеночников Северного Урала (Республика Коми). - [On the liverwort flora of Northern Ural (Komi Repablic)] В кн.: Ботанические исследования на охраняемых природных территориях европейского северо-востока. Тр. Коми науч. иентра УрО Ран, № 165. Сыктывкap [In: Botanicheskie issledovaniya na ohranyaemyh territoriyah evropejskogo severo-vostoka. Trudy Komi nauchnogo centra UrO RAN, N 165, Syktyvkar]: 200207. Annotated list of 82 species.

[BAKALIN, V.A., E.Ya. MULDIYAROV \& E.D. LAPSHINA] БАКАЛИН, В.А., Е.Я. МУЛЬДИЯРОВ, Е.Д. ЛАПШИНА. 2001. Harpanthus drummondii (Geocalycaceae, Hepaticae) - новый вид для Евразии. - [Harpanthus drummondii (Geocalycaceae, Hepaticae) 
- a new species for the Eurasian flora] Бот. Журн. [Bot. Zhurn] 86(6): 159-162. / The diagnostic characters, description, illustration, ecology, key of Harpanthus species are provided.

[BAKALIN, V.A.] БАКАЛИН, В.А. 2002. Монографическая обработка рода Lophozia (Dum.) Dum. s. str. (Lophoziaceae, Hepaticae). - [Monographic of genus Lophozia (Dum.) Dum. s. str. (Lophoziaceae, Hepaticae)] Автореферат ... канд. биол. наук, М. [Ph. D. Thesis, Moskow]: 1-22.

BAMBE, B. 2001. The bryoflora of Teici Nature Reserve, Latvia. - In: 4th European Conference on the Concervation of Bryophytes. Pruhonice, Czech Republic, 1 July-2July 2001. Pruhonice: 13. The bryoflora includes 210 species. Some species are cited.

BAMBE, B., \& V. LÂRMANIS. 2001. Dabas lieguma Pirtslîcis-Lîkâ atteka mețu îpatnîbas un sünu flora. - [The peculiarities of forests and bryoflora in Nature Reserve Pirtslîcis-Lîkâ atteka] Mețzinâtne. Salaspils, 10(43)'2000: 73-88. /Annoteded list of 74 bryophytes (Latvia).

BAMBE, B. 2001. Mazo upju ieleju briofloras îpatnîbas metos. - [The peculiarities of bryoflora in forests of small river valleys] In: LLU Meța fakultâte. Zinâtniski praktiskâ konference. Referâtu tçzes [In: Theses of scientificpractical conference in Forest faculty of Agricultural University of Latvia], Jelgava: 31-35.

BAMBE, B. 2002. Dabas lieguma "Pilskalnes Siguldiňa" brioflora. - [Bryoflora of Nature Reserve "Pilskalnes Siguldiňa”] Mețzinâtn. Salaspils. 11(44)'2001:111-124./ The annoteded list included 98 bryophytes (Latvia).

BAMBE, B. 2002. Jaunu un retu briofîtu sugu atradnes Latvijâ. - [New and rare bryophyte species in Latvia] Retie augi [Rare Plants]. Rîga: 113-124./ The annoteded list included 16 rare bryophytes.

BAKALIN, V. A. 2001. Notes on Lophozia III. Some taxonomic problems in Lophozia sect. Lophozia. - Arctoa 10: $207-218$.

BAKALIN, V.A. 2003. Notes on Lophozia IV. Some new taxa of Lophozia sensu stricto. - Ann. Bot. Fennici 40(1):47-52.

BAKALIN, V.A. 2003. Notes on Lophozia II. On Lophozia rufescens Schljakov and Lophozia sudetica (Huebener) Grolle var. anomala (Schljakov) Schljakov with notes on allied taxa. - Lindbergia 28:75-79.

BAKALIN, V.A. \& N.A. KONSTANTINOVA [БАКАЛИН B.А., КОНСТАНТИНОВА Н.А.] 2003. Нерaticae Rossica Exsiccata, Kirovsk, MUP "Polygraf”, 19.

[BAKALIN, V.A., N.A. KONSTANTINOVA \& G.V. ZHELEZNOVA] БАКАЛИН, В.А., Н.А. КОНСТАНТИНОВА, Г.В. ЖЕЛЕЗНОВА 2001. К флоре печеночников Северного Урала (Республика Коми). [То the liverwort flora of North Ural (Komi Republic)] Ботанические исследования на охраняемых природных территориях Е6ропейского Северо-Востока, Сыктывкар [Botanichesliye issledovaniya na okhranyaemykh prirodnykh territoriyakh Evropejskogo Severo-Vostoka, Syktyvkar]: 208-216.

[BAKALIN, V. A., N. I. MOLOKOVA, T. N. OTNYUKOVА] БАКАЛИН, В. А., Н. И. МОЛОКОВА, Т. Н. ОТНЮКОВА 2001. К флоре печеночников Тоджинской котловины (Республика Тува, Южная Сибирь).
- [On the liverworts flora of Todzha Valley (Tuva Republic, South Siberia)] Arctoa 10: 19-26.

[BAKALIN, V.A., E.YA. MUL'DIYAROV \& E.D. LAPSHINA] БАКАЛИН, В.А., Е.Я. МУЛЬДИЯРОВ, Е.Д. ЛАПШИНА 2001. Harpanthus drummondii (Geocalycaceae, Hepaticae) - новый вид для флоры Евразии. - [Harpanthus drummondii (Geocalycaceae, Hepaticae) - a new species for the Eurasian flora] Бom. журн. [Bot. Zhurn.] 86(6):159-162.

[BAKALIN, V.A.] БАКАЛИН В.А. 2002. Вторичный центр происхождения видов рода Lophozia (Dum.) Dum. s. str. [The secondary centre of origin of species of Lophozia (Dum.) Dum.s. str.] Актуальные проблемы биологии и экологии: Материалы докладов VIII Молодежной научной конферениии Института Биологии Коми НЦ УрО РАН, Сыктывкар [Aktual'nye problemy biologii I ekologii: Materialy dokladov VIII molodezhnoy konferentsii Instituta Biologii Komi NTs UrO PAN]: 121-123.

БАРЯКИНА, Е.А. 2001. Сравнительный анализ флоры листостебельных мхов районов Большого Кавказа. В кн.: Бильги. Баку: 78-84.

БАРЯКИНА, Е.А. 2002. Листостебельные мхи КубаХачмасской зоны (флористическое и эколого-ценотическое исследование). - [Mosses of KubaHachmasskoj zone (floristical and ecology-ceonolgy investigation)] Автореферат ... канд. биол. наук, Баку. [Ph. D. Thesis, Baku]: 1-27.

[BARDUNOV, L.V. \& V.YA. CHERDANTSEVA, V. YA.] БАРДУНОВ, Л.В., В.Я. ЧЕРДАНЦЕВА. 1999.Основные экологические группы листостебельных мхов в лесах южного Сихотэ-Алиня. - [Main ecological groups of mosses in the forest of the south SikhoteAlin] В кн.: Леса и лесообразовательный прочесс на Дальнем Востоке: Материаль международной конферениии, посвященной 90-летию со дня рождения члена-корреспондента РАН Б.П.Колесникова. Влади восток, Биолого-почвенный институт ДВО РАН.[ In: Lesa i lesoobrasovatel'nyj process na Dal'nem Vostoke: Materialy konferencii, posvyashchennoj 90-letiju so dnya rozhdeniya B.P. Kolesnikova. Vladivostok,Biologopochvennyj institute DVO RAN ]: 164-166. / More than 250 species of bryophytes are known from forests. Some species are cited and groups are circumscribed.

[BARDUNOV, L.V. \& V.YA. CHERDANTSEVA, V. YA.] БАРДУНОВ, Л.В., В.Я. ЧЕРДАНЦЕВА. 2001. Субтропические виды мхов в лесах юга российского Дальнего Востока. - [Subtropical moss species in the southern forests of the Russian Far East] В кн.: Классификаиия и динамика лесов Дальнего Востока: Материалы международной конферениии, 5-7 сентября 2001 г. Влади восток. Дальнаука [In: Klassifikaciya i dinamika lesov Dal'nego Vostoka: Materialy konferencii, 5-7 September 2001, Vladivostok, Dal'nauka] : 192-194 /32 subtropical mosses are cited.

[BARDUNOV, L.V., S.K. GAMBARYAN \& V.YA. CHERDANTSEVA] БАРДУНОВ, Л.В., С.К. ГАМБАРЯН, В.Я. ЧЕРДАНЦЕВА. 2002. Мохообразные [Bryophytas] В кн.: Флора, микобиота и растительность ЛІазовского заповедника. Владивосток: Русский Остров [In: Flora, mikobiota i rastitel'nost' Lazovskogo zapovednika. Vladivostok: Russkij ostrov]: 49-67. 
[BELKINA, O. А.] БЕЛКИНА, О. А. 2001. Находка Tetrodontium repandum (Funck) Schwaegr. (Musci) в России. - [New record of Tetrodontium repandum (Funck) Schwaegr. (Musci) in Russia] Arctoa 10: 71-74.

[BELKINA, O.А.] БЕЛКИНА, О.А. 2001. Листостебельные мхи антропогенных местообитаний Мурманской области. - [Mosses of anthropogenic habitats in Murmansk region] Бот. Журн. [Bot. Zhurn] 86(11): 2136. Annoteded list of 135 mosses, and flora analyse.

[BELKINA, O.A. \& A.Yu. LIKHACHEV] БЕЛКИНА, О.А., А.Ю. ЛИХАЧЕВ 2001. Аннотированный список мхов. - [Annotated list of mosses] B кн.: Мохообразные и сосудистые растения территории Полярно-альпийского ботанического сада (Хибинские горы, Кольский полуостров) (ред. Константинова, Н.А.) Апатиты, из-во КНЦ РАН. [In: Konstantinova, N.A. Bryophytes and vascular plants of the territory of Polar Alpine Botanical Garden (Khibiny Mountains, Kola Peninsula). Apatity, izd-vo KNC RAN]: 30-45. / Annoteded list of 205 mosses.

[BELKINA, O.A. \& A.Yu. LIKНACHEV] БЕЛКИНА, О.А., А.Ю. ЛИХАЧЕВ.2002. К вопросу об изученности флор листостебельных мхов заповедников Мурманской области. - [On the state of exploration of moss floras of reserves of Murmansk Province] "[90-летие]": 17-19.

[BELKINA, O.A. \& A.Yu. LIKHACHEV] БЕЛКИНА, О.А., А.Ю. ЛИХАЧЕВ. 2003. Изучение флор листостебельных мхов на особо охраняемых природных территориях Мурманской области (современное состояние и перспективы). - [Investigation of moss floras in strict protected natural territories of Murmansk Province (current state and prospectives)] "[ХІ съезд РБО]": 198-199.

[BEREZINA, A.Yа.] БЕРЕЗИНА, А.Я. 2003. Бриофлора скалистых обнаженией Урала. - [Bryoflora of rock of Ural] “[ХІ съезд РБО]": 199-200.

[BEzGODOV, A. G.] БЕЗГОДОВ, А. Г. 2003 '2002'. К бриофлоре окрестностей Кунгура (Пермская область). - [On the bryoflora of the Kungur City environs (Perm Province)] Arctoa 11: 53-62.

[BLAGODATSKIKH, L.S. \& L.T. PLUZHNIKOV] БЛАГОДАТСКИХ, Л.С., Л.Т. ПЛУЖНИКОВ. 1998. Материалы к бриофлоре Оренбургской области. - [On bryoflora of Orenbugr Province] В кн.: Проблемы ботаники на рубеже XX-XXI веков. Тез. док., представленных II(X) съезду Русского ботанического общества (26-29 мая 1998, Санкт-Петербург). Т. 2. СПб: Ботанический ин. РАН [In: Problems of the botanical sciences at the boundary of $X X$ and $X X I$ centuries: Abstract, presented to the II( $X)$ Congress of the Russian Botanical Society (26-29 May, 1998, St.Peterburg). Vol. 2. St.Peterburg: Komarov Botanical Institute]: 129.

[BOIKO, M.F.] БОЙКО, М.Ф. 1999. Мохообразные в ценозах степной зоны Европы. - [Bryophyta in the coenoses of the steppe zone of Europe] Херсон [Kherson]: 1-159. The life cycles, sexual types, life strategies, etc. of mosses of steppe zone are analyzed.

[BORISENKO, A.L.] БОРИСЕНКО, А.Л. 2001. Географический анализ бриофлоры города Северска (Томская область). - [Geographical analyze of bryoflora of Seversk Sity (Tomsk Province)] В кн.: Исследования молодых ботаников Сибири: Тезисы докладов молодежной конференции (Новосибирск, 20-22 февраля
2001). Новосибирск.[In: Issledovaniya molodyh botanikov Sibiri: Tezisy dokladov molodezhnoj konferencii (Novosibirsk, 20-22 February, 2001)]: 12.

[BORISENKO, A.L.] БОРИСЕНКО, А.Л. 2001. О моховидных "Красной книги Томской области”. - [About bryophytes of "Red Book of Tomsk Province"] $B$ кн.: Проблемы охраны растительного мира Сибири: Тезисы докладов международного совещания (Новосибирск, 21-24 августа 20012.). Новосибирск. [In: Problemy ohrany rastitel'nogo mira Sibiri: Tezisy dokladov mezhdunarodnogo soveshchaniya (Novosibirsk, 21-24 August 2001) Novosibirsk]: 17-18 ./ 11 rare mosses are discussed (West Siberia).

[BORISENKO, A.L.] БОРИСЕНКО, А.Л. 2001. Бриофлора г.Северска как показатель экологического состояния территории. - [Bryoflora of Seversk Sity as

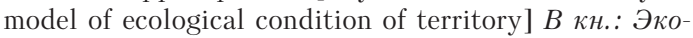
логические проблемы и пути их решения: Сборник научных трудов аспирантов и студентов. Томск.[In: Ecologicheskie problemy $i$ puti ih resheniya: Sbornik nauchnyh trudov aspirantov $i$ studentov. Tomsk]: 90106. List of 85 mosses and analysis of bryoflora.

[BORISENKO, A.L.] БОРИСЕНКО, А.Л. 2002. Бриофлора юго-востока Томской области. - [Bryoflora of south-east of Tomsk Region] Aвтореферат ... канд. биол. наук, Томск. [Ph. D. Thesis, Tomsk]: 1-23.

[BORISENKO, A.L, E.Ya. MULDIYAROV \& E.D. LAPSHINA] БОРИСЕНКО, А.Л., Е.Я. МУЛЬДИЯРОВ, Е.Д. ЛАПШИНА. 2002. Анализ бриофлоры юговостока Томской области - [The analyze of bryoflora of south-west of Tomsk Region] В кн.: Вестник Томского государственного университета. Томск. Прил.2 [In: Vestnik Tomskogo gosudarstvennogo universiteta. Tomsk. Pril. 2]: 14-21.

[BORISENKO, A.L, E.Ya. MULDIYAROV \& E.D. LAPSHINA ] БОРИСЕНКО, А.Л., Е.Я. МУЛЬДИЯРОВ, Е.Д. ЛАПШИНА. 2002. К проблеме географического анализа региональных бриофлор - [On geographical analysis of regional bryofloras] "[90-леmue]": 19-21.

[ВОYСНUK, М.А.] БОЙЧУК, М.А. 2001. Сравнение локальных бриофлор Карелии. - [A comparison of local bryofloras of Karelia] "Anamumb-2001": 12-13.

[BOYCHUK, M.A. \& V.K. ANTIPIN] БОЙЧУК, М.А., В.К. АНТИПИН. 2001. Бриофлора болот национального парка “Водлозерский”. - [Bryoflora of Vodlozero National park mires] В кн.: Национальный парк “Водлозерский” : природное разнообразие и культурное наследие. Петрозаводск. [In: Nacional'nyj park "Vodlozerskij": prirodnoe paznoobrazie i kul'turnoe nasledie. Petrazavodsk]: 162166. Annotated list of 91 mosses.

[ВОҮСНUК, М.А.] БОЙЧУК, М.А. 2001. К флоре листостебельных мхов заповедника Костомукшский и окрестностей города Костомукша (Карелия). - [On moss flora of Kostomukshsky Nature Reserve and Kostomuksha vicinity (Karelia)] Новости сист. низи. pacm. [Novosti Sist. Nizch. Rast.] 35: 217-229. / Annotated list of 175 mosses.

[ВОYСНUК, М.А.] БОЙЧУК, М.А. 2001. Листостебельные мхи особо охраняемых природных территорий Карелии. - [Mosses of protection of natural territories 
of Karelia] Aвтореферат ... канд. биол. наук, СПб. [Ph. D. Thesis, Sankt-Petersburg]: 1-25.

[BOYCHUK, M.A., V.K. ANTIPIN, V.A. BAKALIN \& P.N. LAPSHIN] БОЙЧУК, М.А., В.К. АНТИПИН, В.А. БАКАЛИН, П.Н. ЛАПШИН. 2002. Материалы к изучению бриофлоры Водлозерского Национального парка. - [Contribution on the bryoflora of Vodlozero National park] Новости сист. низи. pacm. [Novosti Sist. Nizch. Rast.] 36: 213-224. / Annotated list of 161 mosses and 24 liverworts (Karelia).

[BUDYAKOVA, A. A., S. P. YATSENTYUK, S. HUTTUNEN, I. A. MILYUTINA, V. K. BOBROVA, M. S. IGNATOV, A. V. TROITSKY] БУ ДЯКОВА, А. А., С. П. ЯЦЕНТЮК, С. ХАТТАНЕН, И. А. МИЛЮТИНА, В. К. БОБPOBА, М. С. ИГНАТОВ, А. В, ТРОИЦКИЙ 2003. Предварительные данные по анализу межроруляционного разнообразия у зеленых мхов Eurhynchium angustirete и Brachythecium salebrosum молекулярными методами. - [Preliminary data on Interpopulation diversity of mosses Eurhynchium angustirete and Brachythecium salebrosum by molecular methods]. Тезисы докл. ХI международного совещания по филогении растений. M., МГУ и др. [Abstr. XI soveshchaniya po filogenii rastenij. Moscow, Mosk. Gos. Univ. ]: 27-28.

[BUGAKOVA, T.S.] БУГАКОВА, Т.C. 2002. К оценке видового разнообразия мохообразных кальцефитнопетрофитных степей. - [To an assessment of a species diversity of bryophytes of carbonate-petrous steppes] "[90-летие]": 21-23.

[CHERDANTSEVA, V. ҮA.]ЧЕРДАНЦЕВА, В.Я. 1998. Материалы к бриофлоре Сихотэ-Алинского биосферного заповедника. - [On bryoflora of Sikhote-Alin Biosphere Reserve] В кн.: Растения в муссонном климате: Материаль междун. конферениии, посвященной 50-летию Ботанического сада-института ДВО РАН (Ред. O.В. Храпко).Владивосток, Дальнаука [In: Chrapko, O.V. (ed.) Rasteniya v mussonnom klimate: Materialy mezhdun. konferencii, posvyashchennoj 50-letiju Botanicheskogo sadainstituta DVO RAN. Vladivostok, Dal'nauka]: 73-75. Flora includes 186 species, some species are cited.

[CHERDANTSEVA, V. YA.] ЧЕРДАНЦЕВА, В.Я. 2000. Род Gollania (Musci, Нурnaceae) на российском Дальнем Востоке. - [Genus Gollania (Musci, Hypnaceae) in the Russian Far East] В кн.: Растения муссонного климата: Тезисы. II-ой международной конференции "Растения в муссонном климате". (Ред. Храпко, О.В.). Владивосток. Дальнаука [In: Hrapko, O.V. Rasteniya mussonnogo klimata: Tezisy II mezhdun. konferencii "Rasteniya $v$ mussonnom klimate". Vladivostok, Dal'nauka]: 239-240. The genus Gollania is represented on the Russian Far East by 1 species - Gollania ruginosa.

[CHERDANTSEVA, V. YA.]ЧЕРДАНЦЕВА, В.Я. 2002. Обзор бриофлоры южного Сахалина. - [Review of bryoflora of South Sahalin] "[90-летие]": 66-67.

[CHERDANTSEVA, V. ҮA.] ЧЕРДАНЦЕВА, В. Я. 2003 '2002'. Листостебельные мхи Сихотэ-Алинского биосферного заповедника (Дальний Восток, Приморский край). [Mosses of the Sikhote-Alinsky Biosphere Reserve (Russian Far East, Primorsky Territory)] Arctoa 11: 229-244.

[CHERDANTSEVA, V. YA.]ЧЕРДАНЦЕВА, В.Я. 2003. Семейство Thuidiaceae (Bryophyta: Musci) на Россий- ском Дальнем Востоке. - [Family Thuidiaceae (Bryophyta: Musci) on Russian Far East] "[XI съезд PБO]": 221-222.

[CHERDANTSEVA, V. YA. \& L. N. EGOROVA] ЧЕРДАНЦЕВА, В.Я., Л. Н. ЕГОРОВА 2001. Памяти Стеллы Казаровны Гамбарян (1946-2000). - [Stella Kazarovna Gambaryan (1946-2000)] Arctoa 10: 237-242.

[CHURAKOVA, E. N.] ЧУРАКОВА, Е. Н. 2003 '2002'. Листостебельные мхи таёжной зоны Архангельской области. - [Mosses of the taiga zone of the Arkhangelsk Province (northern European Russia)] Arctoa 11: 351-392.

[CZERNYADJEVA, I.V.] ЧЕРНЯДЬЕВА, И.В. 2001. Редкие мхи полуострова Ямал. - [Rare mosses of Yamal Peninsula] "Anamumb-2001": 42-44.

[CZERNYADJEVA, I.V.] ЧЕРНЯДЬЕВА, И.В. 2001. Листостебельные мхи заповедника Большая Кокшага (Республика Марий Эл). - [Mosses of Bol'shaya Kokshaga Reserve (Mari El Republic, European Part Russia] Hовости сист. низи. pacm. [Novosti Sist. Nizch. Rast.] 35: 266-278. Annotated list of 149 mosses.

CZERNYADJEVA, I.V. [ЧЕРНЯДЬЕВA, И.В.] 2001. The mosses of Kochelevsky Volcano. - In: Abstracts of the Kamchatka Field Symposium "Plants and Volcanoes", Petropavlovsk-Kamchatskiy, Russia, 9-15 July 2001. Vladivostok: 14./Some mosses are cited.

CZERNYADJEVA, I. V. 2001. Moss flora of Yamal Peninsula (West Siberian Arctic). - Arctoa 10: 121-150.

CZERNYADJEVA, I. V. \& M. S. IGNATOV 2001. Recent bryological literature of CIS and Baltic countries. V. Arctoa 10: 243-258.

CZERNYADJEVA, I. V. 2003 '2002'. Dichelyma capillaceum (Dicks.) Myr. (Musci) in Russia - Arctoa 11: 87-89.

[CZERNYADJEVA, I. V.] ЧЕРНЯДЬЕВА, И. В. 2003 '2002'. Листостебельные мхи бассейна р. Левый Кихчик (Дальний Восток, Западная Камчатка). - [Mosses of basin of Left Kihchik River (Far East, West Kamtchatka)] Arctoa 11: 91-100.

[CZERNYADJEVA, I.V. (CHERNYAD'EVA)] ЧEPHЯДЬЕВА, И.В. 2002. Новые находки редких и интересных видов листостебельных мхов на полуострове Камчатка. - [New records of rare and interesting species of Bryopsida of Kamchatka Peninsula] B кн.: Coxpaнение биоразнообразия Камчатки и прилегающих морей. Материалы ІІІ научной конф. 27-28 ноября 2002 2. Петропавловск-Камчатский, Изд-во КамчатНИРО. [In: Conservation of biodiversity of Kamchatka and coastal waters. Materials of III scientific conference. Petropavlovsk-Kamchatsky, November 27-28 2002. Petropavlovsk-Kamchatsky, Izda-vo KamchatNIRO]: 103-106. / Data on distribution of 18 rare species.

[CZERNYADJEVA, I.V.] ЧЕРНЯДЬЕВА, И.В. 2002. Редкие виды во флоре листостебельных мхов полуострова Ямал (Западно-Сибирская Арктика). - [Rare species on moss flora of Yamal Peninsula (West-Siberian Arctic] Бот. Журн. [Bot. Zhurn] 82(7): 93-101. / The data about of 78 rare mosses are provided.

[CZERNYADJEVA, I.V.] ЧЕРНЯДЬЕВА, И.В. 2002. История изучения бриофлоры полуострова Камчатка. - [History of studies of bryoflora of Kamchatka Peninsula] "[90-летие]": 67-69. 
[CZERNYADJEVA, I.V. \& A.D. POTEMKIN] ЧЕРНЯДЬЕВА, И.В., А.Д. ПОТЕМКИН. 2002. ФЛора мохообразных заповедника. - [The bryoflora of the Reserve] В кн.: Растительность, флора и почвы Верхне-Тазовского Государственного заповедника (ред. В.Ю. Неuamaes). [In: V.Yu. Neshatayev. Vegetation, flora and soils of the Verhne-Tazovskii State Reserve. SanktPetersberg]: 35-46. The annotated list includes 126 mosses and 39 liverworts (Upper Taz River, Western Siberia).

[CZERNYADJEVA, I.V. \& A.D. POTEMKIN] ЧЕРНЯДЬЕВА, И.В., А.Д. ПОТЕМКИН. 2002. Флора мохообразных. - [The bryoflora] $В$ кн.: Флора и растительность южной Камчатки (на примере Южно-Камчатского Федерального заказника) (ред. В.Ю. Нешатаева). Петропавловск-Камчатский[Іп: V.Yи. Neshataeva. Flora i rastitel'nost' juzhnoj Kamchatki (na primere Juzhno-Kamchatskogo Federal'nogo zakaznika. Petropavlovsk-Kamchatskij]: 44-66. / The annotated list includes 159 mosses and 38 liverworts.

[CZERNYADJEVA, I.V. \& E.Yu. KUZMINA] ЧЕРНЯДЬЕВА, И.В., Е.Ю. КУЗЬМИНА. 2002. Мхи окрестностей города Сургут (Западная Сибирь). - [Mosses of Surgut surroundings (Western Sibiria)] Новости сист. низи. pacm. [Novosti Sist. Nizch. Rast.] 36: 254-269. Annotated list of 111 mosses and 17 liverworts.

[DEGTEVA, S.V., G.V. ZHELEZNOVA, T.N. PYSTINA \& T.P. SHUBINA] ДЕГТЕВА С.В., Г.В. ЖЕЛЕЗНОВА, Т.Н. ПЫСТИНА, Т.П. ШУБИНА. 2001. Ценотическая и флористическая структура лиственных лесов европейского Севера. - [Plant and floristic structure of the deciduous forests on the European North] Санкm-Петербург [Sankt-Petersburg]: 1-269./Some mosses are cited.

[DEGTEVA, S.V., T.N. PYSTINA \& T.P. SHUBINA] ДЕГТЕВА С.В., Т.Н. ПЫСТИНА, Т.П. ШУБИНА. 2001. Лиственные леса Республики Коми как местообитания редких видов. - [Deciduous forests of the Komi Republic as habitat of rare species] B кн.: Ботанические исследования на охраняемых природных территориях Европейского Северо-Востока. Тр. Коми научного чентра УрО Российской АН. Сыктывкар [In: Botanicheskie issledovaniya na ohranyaemyh prirodnyh territoriyah Evropejskogo Severo-Vostoka. Trudy Komi nauchnogo tsentra, Syktyvkar]: 165: 114-127.

[DEGTEVA, S.V., G.V. ZHELEZNOVA, V.A. KANEV, D.A. KOSOLAPOV, A.A. KUSTYSHEVA, V.V. MOKIEV, T.N. PYSTINA, B.Y. TETERYUK \& T.P. SHUBINA] ДЕГTEBA С.В., Г.В. ЖЕЛЕЗНОВА, В.А. КАНЕВ, Д.А. КОСОЛАПОВ, А.А. КУСТЫШЕВА, В.В. МОКИЕВ, Т.Н. ПЫСТИНА, Б.Ю.ТЕТЕРЮК, Т.П. ШУБИНА. 2002. Комплексные исследования ландшафтного заказника “Сэбысь” (Республика Коми). - [Complex investigations in the Nature Reserve "Sebys" (Komi Republic)] В кн.: Современные проблемы природопользования, охотоведения и звероводства. Мат. Межд. Научно-практической конф., посвященной 80-летию ВНИИОЗ (28-31 мая 2002 г.) Киров [In: Sovremennye problemy prirodopolzovania, ohotovedenia i zverovodstva. Materialy konf. 28-31 May, 2002, Kirov]: 438-439. / The moss flora of reserve includes 93 species, including Dichelyma falcatum and Sphagnum platyphyllum.

[DEGTEVA, S.V., G.V. ZHELEZNOVA \& T.P. SHUBINA]
ДЕГТЕВА С.В., Г.В. ЖЕЛЕЗНОВА, Т.П. ШУБИНА. 2002. Оценка состояния растительности и флоры Зеленоборского стационара как основа долговременного мониторинга. - [Estimation of state of vegetation and flora of the Zelenoborsk station for long-stading monitoring] В кн.: Экология северных территорий России. Проблемь, прогноз, ситуачии, пути развития, решения. Том 1. Мат. Межд. Конф. Архангельск [In: Ekologiya severnyh territorij Rossii. Problemy, prognoz, situacii, puti razvitiya, resheniya. Vol. I. Materialy mezhdunarodnoj konf. Arhangel'sk]: 542-546. / The moss flora includes 89 moss species, some species are cited.

[DEGTYAREVA, S.I.] ДЕГТЯРЕВA, С.И. К изучению мохового компанента лесостепных дубрав. - [On the study of moss companent of forest-steppes oak forests] "[90-летие]": 23-25.

[DEMIDOVA, E. E., V. R. FILIN] ДЕМИДОВА, Е. Е., В. P. ФИЛИН 2001. Строение блефаропласта Tayloria tenuis (Dicks.) Schimp. (Musci, Splachnaceae). [Blepharoplast structure in Tayloria tenuis (Dicks.) Schimp. (Musci, Splachnaceae)] Arctoa 10: 75-82.

[DOROSHINA-UKRAINSKAYA, G.Ya.] ДОРОШИНАУКРАИНСКАЯ, Г.Я. 2002. К бриофлоре Псковской области. - [On bryoflora Pskov Province] Новости сист. низи. pacm. [Novosti Sist. Nizch. Rast.] 36: 224-230.

Annotated list of 82 mosses and 15 liverworts.

[DOROSHINA-UKRAINSKAYA, G.Ya.] ДОРОШИНАУКРАИНСКАЯ, Г.Я. 2002. Материалы к бриофлоре заповедника “Нургуш” (Кировская область). [Contribution to the bryoflora of "Nurgush" reserve (Kirov Province)] Новости сист. низи. pacm. [Novosti Sist. Nizch. Rast.] 36: 230-236/Annotated list of 87 mosses and 12 liverworts (European Russia).

[DOROSHINA-UKRAINSKAYA, G.Ya.] ДОРОШИНАУКРАИНСКАЯ, Г.Я. 2002. Род Plagiothecium B.S.G. в бриофлоре России. - [Genus of Plagiothecium B.S.G. in bryoflora of Russia] Автореферат ... канд. биол. наук., СПб [Ph. D. Thesis, Sankt-Petersburg] : 1-20.

[DOROSHINA-UKRAINSKAYA, G.Ya.] ДОРОШИНАУКРАИНСКАЯ, Г.Я. 2002. Вегетативное размножение у видов рода Plagiothecium. - [Vegetative reproduction in species of the genus Plagiothecium] "[90-летие]": 25-26.

[DYACHENKO, А.P.] ДЬЯЧЕНКО, А.П. 2002. Проблемы бриологии Урала. - [The problems of bryology of Ural] "[90-летие]": 26-27.

[DULIN, M.V.] ДУЛИН, M.B. 2002. Анализ флоры печеночников окрестностей Кадамских озер (Усть-Куломский район, Республика Коми). - [Analisis of the liverwort flora of the Kadam Lakes vicinity (Ust-Kulom region, Komi Republic)] В кн.: Актуальные проблемы биологии и экологии. (Мат. докл.) VIII Молодежная науч. конф. 18-20 апреля 2001 г., Сыктывкар, Республика Коми, Россия. [In: Aktualnye problemy biologii $i$ ekologii. Materialy dokladov. IX Molodezhnaya nauchnaya konf. 18-20 April 2001, Syktyvkar, Komi Republic, Russia]: 133-136. / Liverwort flora includes 40 species, some species are cited.

[DULIN, M. V.] ДУлИН, М. В. 2001. Новые находки редких и интересных печеночников в республике Коми (Северо-Восток Еевропейской России). - [New records of rare and interesting liverworts in Komi Republic 
(North-East European Russia)] Arctoa 10: 27-30.

[DULIN, M.V.] ДУЛИН, М.В. 2002. Анализ флоры печеночников лесного заказника "Порубский”. - [Analysis of the liverwort flora of the forest reserve "Porubskij"] $B$ кн.: Актуальные проблемы биологии и экологии. (Тез. докл.) ІХ Молодежная науч. конф. 15-17 апреля 2002 2., Сыктывкар, Республика Коми, Россия. [Іп: Aktualnye problemy biologii i ekologii. Tezisy dokladov. IX Molodezhnaya nauchnaya konf. 15-17 April 2002, Syktyvkar, Komi Republic, Russia]: 43-44.

EFREMOV, S. P. \& T. T. EFREMOVA 2000. Structure and productivity of Sphagnus moss communities on swamps of West Siberia. - Sibirskii Ekol. Zhurn. 7: 62-63.

[FILIN, V.P.] ФИЛИН, В.P. 2002. Спорофит плауновидных и побег мохообразных - случайное сходство или проявление гомеозиса? - [Sporophyte of lycopods and bryophyte shoot - occasional similarity or homeotic effect] "[90-летие]" : 62-63.

[GALANINA, O.V., E.N. ANDREJEVA \& E.O. KUZMINA] ГАЛАНИНА, О.В., Е.Н. АНДРЕЕВА, Е.О. КУЗЬМИНА. 2001. Растительный покров охраняемой части Кудровского болота (Ленинградская область). [Vegetation cover of the protected part of Kudrovskoye mire (Leningrad region)] Бот. Журн. [Bot. Zhurn] 86(11): 109-121. /50 bryophytes are cited.

[GAMBARYAN, S. K.] ГАМБАРЯН, С. К. 2001. Печеночники Сихотә-Алинского заповедника (Приморский край). - [Liverworts of the Sikhte-Alin Reserve (Primorsky Territory)] Arctoa 10: 31-42.

[GAMBARYAN, S.K. \& V. Ya. CHERDANTSEVA] ГAMБАРЯН, С.К., В.Я. ЧЕРДАНЦЕВА. 2002. Мохообразные. - [Bryophyta] B кн.: Кадастр растений и гри бов заповедника “Кедровая Падь”. Владивосток, Дальнаука [In: Kadastr rastenij i gribov zapovednika "Kedrovaya Pad"”. Vladivostok, Dal'nauka]: 21-30 / List included 30 liwervorts and 149 mosses (Far East).

GOFFINET, B. 2003 '2002'. Orthotrichum sprucei Mont. (Musci), a European endemic discovered in Kazakhstan - Arctoa 11: 27-30.

GOLDBERG, I. L. 2003 '2002'. The saxicolous moss flora of the Middle Urals - Arctoa 11: 63-80.

[GOLDBERG, I. L.] ГОЛЬДБЕРГ, И. Л. 2003 '2002'. Материалы к флоре листостебельных мхов скальных обнажений Северного Урала. - [Contribution to the saxicolous moss flora of the Northern Urals] Arctoa 11: $81-86$.

[GONCHAROVA, I.A.] ГОНЧАРОВА, И.А. 2003. Особенности структуры моховых дерновин на болотах различных типов водно-минерального питания. [Features of structure of moss mats in bogs with various types of water-mineral nutrition] "[XI съезд РБО]": 202-203.

[GONCHAROVA, I.A.] ГОНЧАРОВА, И.А. 2003. Динамика приростов зеленых мхов в лесоболотных комплексах Западной Сибири. - [Dynamics of accretions of green mosses in forest-bogs complexes of Western Siberia] "[ХІ съезд РБО]”: 203-205.

[GOROBETS, K.V. \& V. YA. CHERDANTSEVA] ГOPOБЕЦ, К.В., В.Я. ЧЕРДАНЦЕВА 1999. Листостебельные мхи (Musci, Bryophyta) Ботанического сада-ин-та ДВО
PAH. - [The mosses (Musci, Bryophyta) of the botanical garden-institute (Vladivostok)] В кн.: Исследование растительного покрова российского Дальнего Востока. Тр. ботанических садов ДВО РАН. Т. І. (Ред. Недолужко, В.А.). Владивосток. Дальнаука. [In: Nedoluzhko, V.A. Issledovanie rastitel'nogo pokrova rossijskogo Dal'nego Vostoka. Trudy botanicheskih sadov DVO RAN. T. I. Vladivostok, Dal'nauka]: 26-34. / Annoteded list of 82 species.

[GOROBETS, K.V. \& V. YA. CHERDANTSEVA] TOPOБЕЦ, К.В., В.Я. ЧЕРДАНЦЕВА. 2002. Мхи острова Аскольд (Японское море, залив Петра Великого). [Mosses of Askold Island (Yaponskoe Sea, gulf Petr Great] В кн.: III-я региональная конференция по актуальным проблемам морской биологии, экологии и биотехнологии студентов, аспирантов и молодых ученых ДВГУ. Тезисы докладов. Изд-во ДВГУ, Владивосmок [In: 3 regional'naya konferenciya po aktual'nym problemam morskoj biologii, ekologii $i$ biotehnologii studentov, aspirantov i molodyh uchenyh DVGU. Tezisy dokladov. Isd-vo DVGU, Vladivostok] : 29-31.

[GOROBETS, K.V.] ГОРОБЕЦ, К.В. 2003. Мхи архипелага Римского-Корсакова (залив Петра Великого, Японское море). - [Mosses of Rimskij-Korsakov Archipelago (the Retr Great Gulf, Japan Sea)] "[XI съезд РБО]": 205-206.

IGNATOV, M. S. 2001. Moss diversity in the Western and Northern Palearctic. - Arctoa 10: 219-236.

IGNATOV, M. S. \& S. HUTTUNEN 2003 '2002'. Brachytheciaceae (Bryophyta) - a family of sibling genera - Arctoa 11: 245-296.

IGNATOV, M. S. \& E. A. IGNATOVA 2001. On the zoochory of Schistostega pennata (Schistostegaceae, Musci). Arctoa 10: 83-96.

[IGNATOV, M. S. \& E. A. IGNATOVA] ИГНАTOB M.C., Е.А.ИГНАТОВА 2003. Флора мхов средней части европейской России. Том 1. Sphagnaceae - Hedwigiaceae. - [Moss flora of the Middle European Russiaю Vol. 1. Sphagnaceae - Hedwigiaceae] M., KMK [Moscow, KMK], 608 pp. / сем. Bryасеае - в обработке В. И. Золотова-см.

[IGNATOV, M. S., E. A. IGNATOVA \& T. V. AKATOVA] ИГНАТОВ, М. С., Е.А. ИГНАТОВА, Т.В. АКАТОВА 2002. Средиземноморский флористический элемент во флоре мхов Кавказского заповедника. - [Mediterranean floristic element in moss flora of Caucasian Reserve] В кн.: Актуальные проблемы экологии в условиях современного мира. Материаль Второй международной научно-практ. конф. Майкоп [In: Aktualnye problemy ekologii v usloviyakh sovremennogo mira. Mat. 2 mezhdun. konf., Maikop]: 86-88.

IGNATOV, M. S., E. A. IGNATOVA, T. V. AKATOVA \& N. A. KONSTANTINOVA 2003 '2002'. Bryophytes of the Khosta' Taxus and Buxus Forest (Western Caucasus, Russia). - Arctoa 11: 205-214.

IGNATOV, M. S., E. A. IGNATOVA \& S. A. SURAGINA 2003 '2002'. A new variety of Syntrichia caninervis (Pottiaceae, Musci). - Arctoa 11: 333-336.

IGNATOV, M. S. \& P. ISOVIITA 2003. (1579) Proposal to conserve the name Oxyrrhynchium (Brachytheciaceae, Musci) with a conserved type. - Taxon 52: 352-354.

IGNATOV, M. S., E. I. IVANOVA, E. A. IGNATOVA \& K. K. KRIVOSHAPKIN 2001. On the moss flora of Ust- 
Maya District (Republic Sakha/Yakutia, East Siberia). - Arctoa 10: 165-184.

IGNATOVA, E. A. \& M. S. IGNATOV 2001. Bryoerythrophyllum ferruginascens (Stirt.) Giac. (Pottiaceae, Musci) in Russia. - Arctoa 10: 151-154.

IGNATOVA, E. A. 2001. A new species of Barbula (Pottiaceae, Musci) from Siberia. - Arctoa 10: 161-164.

INGERPUU, N. 2002. Bryophyte diversity and vascular plants. - Dissert. Biol. Univ. Tartuensis 75: 1-32+ copies of $5 \mathrm{msc}$.

INGERPUU, N., K. VELLAK, T. KUKK, M. PÄRTEL 2001. Bryophyte and vascular plant species richness in boreonemoral moist forests and mires. - Biodiversity and Conservation 10: 2153-2166.

[IVANOVA, E.I.] ИВАНОВА, Е.И. 2002. Бриологическая коллекция института биологических проблем криолитозоны CO PAH. - [Bryologycal collection of biological problems of kriolitozone of SO RAN institute] "[90-летие]": 28-30.

[IVANOVA, E.I.] ИВАНОВА, Е.И. 2003. Бриофлора нарушенных местообитаний Южной Якутии. - [Bryoflora of disturbed places in South Yakutiya] Наука и образование (Якутск) [Nauka i obrazovanie (Yakutsk)] № 1(29): 5-7.

IVANOVA, E.I. A study of bryoflora of Yakutia (A.K. Cajander collections). - Мат. междунар. Саха-Финляндской конф., посв. 100-летию экспедииии А.К. Ка яндера по реке Лене "Проблемы ботанических и лесоводственных исследований в Республике Саха (Якутия) и Финляндии. Якутск: ЯФ Изд-во СО РАН [Mat. mezhdun. Sakha-Finlyandskoj konf., posvyashchennoi 100-letiyu expedizii A. C. Cajandera po reke Lene "Problemy botanicheskikh $i$ lesovodstvennykh issledovanij v respublike Sakha (Yakutiya) $i$ Finlandii. Yakutsk, YF SO RAN]: 53-61.

[IVANOVA, E.I., Е. V. SOFRONOVA] ИВАНОВA, Е.И. Е. В. СОФРОНОВА 2003. К изученности бриофлоры верхнего течения р. Лены (Юго-Западная Якутия). [On the exploration of bryoflora of Upper Lena River (South-West Yakutiya] Mат. междунар. Саха-Финляндской конф., посв. 100-летию экспедиции А.К. Каяндера по реке Лене "Проблемы ботанических и лесоводственных исследований в Республике Саха (Якутия) и Финляндии. Якутск: ЯФ Изд-во СО РАН [Mat. mezhdun. Sakha-Finlyandskoj konf., posvyashchennoi 100-letiyu expedizii A. C. Cajandera po reke Lene "Problemy botanicheskikh i lesovodstvennykh issledovanij v respublike Sakha (Yakutiya) i Finlandii. Yakutsk, YF SO RAN]: 61-65.

KALINAUSKAITE，N. \& J.R. NAUJALIS 2002. Investigations of liverwort flora in protected areas of Litnuania. - "[90-летие]”: 31-32.

[KARAEVA, N. I. \& E. A. BARYAKINA] КAPAEBA, Н.И., Е.А. БАРЯКИНА 2001. Эпилитная флора Куба-Хачмасской зоны. - [Epilithic flora of Kuba-Khachmas Perion] Известия. Биол. науки. Баку [Izv. Bio. Nauki. Baku] 1-3: 12-17.

[KATENIN, A. Е.] КАТЕНИН, А. Е. 2003 '2002'. Памяти Зои Николаевны Смирновой, 1898-1979. - [Zoya Nikolaevna Smirnova, 1898-1979] Arctoa 11: 399-408.
[KAZANOVSKY, S.G.] КАЗАНОВСКИЙ, С.Г. 2003. Реликтовые мохообразные во флоре хребта Хамар-Дабан. - [Relict bryothytes in flora of Khamar-Daban Range] "[ХI съезд РБО]": 206-207.

KONSTANTINOVA, N. A. 2001. Eremonotus myriocarpus (Carr.) Lindb.\& Kaal. - an addition to the hepatic flora of Russia. - Arctoa 10: 115-120.

KONSTANTINOVA, N. A., V. A. BAKALIN, A. D. POTEMKIN, M. S. IGNATOV 2003 '2002'. Hepatic flora of the Upper Bureya River (Russian Far East) - Arctoa 11: 393-398.

[KONSTANTINOVA, N.A.] КОНСТАНТИНОВА, Н.А. 2001. Аннотированный список печеночников (Hepaticae). - [Annotated list of Hepatics] В кн.: Мохообразные $u$ сосудистые растения территории Полярно-альпийского ботанического сада (Хибинские горы, Кольский полуостров) (ред. Константинова, Н.А.) Aпатиты, из-во КНЦ РАН. [In: Konstantinova, N.A. (ed.) Bryophytes and vascular plants of the territory of Polar Alpine Botanical Garden (Khibiny Mountains, Kola Peninsula). Apatity, izd-vo Kolsk. Nauchn. Centra Ross. Akad. Nauk]: 15-29. Annotated list of 105 liverworts.

[KONSTANTINOVA, N.A.] КОНСТАНТИНОВА, Н.А. 2001. Введение. - [Introduction] В кн.: Мохообразные и сосудистые растения территории Полярноальпийского ботанического сада (Хибинские горы, Кольский полуостров) (ред. Константинова, Н.А.) Anaтиты, из-во КНЦ РАН. [In: Konstantinova, N.A. Bryophytes and vascular plants of the territory of Polar Alpine Botanical Garden (Khibiny Mountains, Kola Peninsula). Apatity, izd-vo KNC RAN]: 5-7.

[KONSTANTINOVA, N.A.] КОНСТАНТИНОВA, Н.A. 2001. Видовое разнообразие и таксономические спектры некоторых локальных флор печеночников Мурманской области. - [Species diversity and taxonomical spectrum of some local liverwort floras of Murmanskaya region] "Anamumbl-2001": 20.

[KONSTANTINOVA, N.A.] КОНСТАНТИНОВА, Н.А. 2001. State of knowledge on Bryophytes of Strict Nature Reserves (Zapovedniki) of European part of Russia. In: Abstracts of 4-th European Conference of the Conservation on Bryophytes. Pruhonice: 10.

[KONSTANTINOVA, N.A.] КОНСТАНТИНОВА, Н.А. 2001. Hepatics in the third edition of Red Data Book of Murmansk Province. - In: Abstracts of 4-th European Conference of the Conservation on Bryophytes. Pruhonice: 19.

[KONSTANTINOVA, N.A.] КОНСТАНТИНОВА, Н.А. 2001. Hepatics in Strict Nature Reserves of European part of Russia. - Novit. Bot. Univ. Carol. 15: 77-93. / The list includes 185 species.

[KONSTANTINOVA, N. A.] КОНСТАНТИНОВА, Н. А. 2003 '2002'. Род Tetralophozia (R.M.Schust.) Schljakov (Lophoziaceae, Hepaticae) в России. - [The genus Tetralophozia (R.M.Schust.) Schljakov (Lophoziaceae, Hepaticae) in Russia] Arctoa 11: 45-52.

[KONSTANTINOVA, N.A. \& E.Yu. KUZMINA] KOHСТАНТИНОВА, Н.А., Е. Ю. КУЗЬМИНА. 2001. К флоре печеночников Корякии (северо-восток России) - [On the hepatic flora of Koryakiya (North East of Russia)] Arctoa 10: 103-114. 
[KONSTANTINOVA, N.A.] КОНСТАНТИНОВА, Н.А. 2002. Редкие и интересные виды печеночников (Hepaticae) в заповеднике Кузнецкий Алатау. - [Rare and interesting liverworts (Hepaticae) in reserve Kuznetskij Alatau] Вестн. Томск. гос. ун-та. Приложение. 2, сентябрь 2002 [Vestn. Tomsk. Gos. Univ., Suppl. 2, sept. 2002]: 28-31.

[KONSTANTINOVA, N.A.] КОНСТАНТИНОВА, Н.А. 2002. Вклад Р.Н.Шлякова в развитие российской бриологии. - [The contribution R.N. Shljakov to the development of Russian bryology] "[90-летие]": 3-7.

[KONSTANTINOVA, N. A. \& E. YU. KUZMNINA] KOHСТАНТИНОВА, Н. А. \& Е. Ю. КУЗЬМИНА 2001. К флоре печеночников Корякии (Северо-Восток России). - [On the hepatic flora of Koryakiya (North East of Russia)] Arctoa 10: 103-114.

[KONSTANTINOVA, N.A. \& A.N. SAVCHENKO] KOHСТАНТИНОВА, Н.А., А.Н.САВЧЕНКО. 2002. Проблема инвентаризации гербарных коллекций и ее решение в Полярно-Альпийском Ботаническом Саду КНЦ PAH (KPABG). - [The inventory of herbarium collections and approach to this in the Polar-Alpine Botanic Garden KSC RAN (KPABG)] “[90-летие]”: 32-33.

[KONSTANTINOVA, N.A. \& O.V. LAVRINENKO] КОНСТАНТИНОВА, Н.А., О.В. ЛАВРИНЕНКО. 2002. К флоре Hераticae Ненецкого автономного округа (северо-восток европейской части России). - [On flora of Hepaticae of the Nenets Autonomous Area (Arkhangelsk Region, north-eastern European Russia] Бот. журн. [Bot. Zhurn] 87(9): 43-49. / Annotated list of 53 liverworts (Calyculasria laxa - new to Europe).

[KONSTANTINOVA, N.A.] КОНСТАНТИНОВА, Н.А. 2003. Печеночники южной Сибири: история изучения, характеристика флоры, направление дальнейших работ. - [Liverworts of South Siberia: history of study, characteristic of flora, direction of the further works] “[ХІ съезд РБО]”: 207-209.

[KOSTINA, V.A., O.A. BELKINA \& N.A. KONSTANTINOVA] КОСТИНА, В.А., О.А. БЕЛКИНА, Н.А. КОНСТАНТИНОВА. 2001. Краткий очерк природных условий. - [Phytogeographic survey] $B$ кн.: Мохообразные и сосудистые растения территории Полярноальпийского ботанического сада (Хибинские горы, Кольский полуостров) (ред. Константинова, Н.А.) Anaтиты, из-во КНЦ РАН. \{In: Konstantinova, N.A. Bryophytes and vascular plants of the territory of Polar Alpine Botanical Garden (Khibiny Mountains, Kola Peninsula). Apatity, izd-vo KNC RAN]: 8-15.

KOSSOVICH, E.I. \& Z.A. TRUKHINA 2003. Gametophyte abnormalities in Sphagnum under technogenic pollution. - “[ХІ съезд РБО]”: 209.

[KRIVOSHAPKIN, K.К.] КРИВОШАПКИН, К.К. 2002. К бриофлоре среднего течения реки Алдан (юго-восточная Якутия). - [To bryoflora of middle corse of Aldan River (south-east Yakutiya)] "[90-летие]": 34-35.

[KRIVOSHAPKIN, K. K., M. S. IGNATOV \& E. A. IGNATOVA] КРИВОШАПКИН, К. К., М. С. ИГНАТОВ, Е. А.ИГНАТОВА 2001. К флоре листостебельных мхов Национального природного парка “Ленские столбы” (устье р. Лабыйа). - [On moss flora of National Nature Park "Lenskie Stolby" (Labyja Creek mouth)] B кн.: Национальный природный парк “Ленские Столбъь” : геология, почвы, растительность, животный мир, охрана и использование. Якутск, НПП “Ленские Стлобb” [In: Nationalnyj Prirodny Park "Lenskie Stolby”: geologiya, pochoy, rastitelnost, zhivotny mir, ochrana $i$ ispolzovanie. Yakutsk, NPP "Lenskie Stolby" \& al.]: 71-81.

[KURBATOVA, L.Е.] КУРБАТОВА, Л.Е. 2001. К флоре листостебельных мхов востока Ленинградской области. - [On moss flora of east of Leningrad Region] Hовости сист. низи. pacm. [Novosti Sist. Nizch. Rast.] 35: 229-239 / The list includes 10 rare species.

[KURBATOVA, L.E.] КУРБАТОВА, Л.Е. 2001. Арктомонтанный и гипоарктический элементы во флоре листостебельных мхов Ленинградской области. - [The arctomontane and hi poaric element in the moss flora of Leningrad region] "Anamumb-2001": 23-24.

[KURBATOVA, L.E.] КУРБАТОВА, Л.Е. 2002. Листостебельные мхи. - [Mosses] B кн.: Комаровский берег - комплексный памятник природы (Ред. Волкова E A, Г.А. Исаченко, В.Н. Храмиов). СПб. [In: Volkova, E.A., G.A. Isachenko \& V.N. Khramzov. Komarovskiy coast - complex natural reserve. Sankt-Petersburg]: 3539. Annotated list of 75 mosses (Leningrad Province).

[KURBATOVA, L.E.,] КУРБАТОВА, Л.Е. 2002. Листостебельные мхи Ленинградской области. - [The mosses of Leningrad region] Автореферат ... канд. биол. наук., CПб [Ph. D. Thesis, Sankt-Petersburg] : 24.

[KURBATOVA, L.E. \& M.G. NOSKOVA] КУРБATOBA, Л.Е., М.Г. НОСКОВА 2002. К флоре зеленых мхов восточной части Финского залива. - [On the moss flora of the east part of the Gulf of Finland] Hовости сист. низи. pacm. [Novosti Sist. Nizch. Rast.] 36: 236-244./ Annotated list of 88 species (Leningrad Province).

[KUVAEV, V. B., A. E. SONNIKOVA, L. G. BYAZROV \& E. A. IGNATOVA] КУВAEB, В. Б., А. Е. СОННИКОВА, Л. Г. БЯЗРОВ, Е. А. ИГНАТОВА 2002. К познанию подгольцовых пустынь Западного Саяна. - [On subalpine "deserts" in Western Sayans] Бот. Журн. [Bot. Zhurn.] 87(4): 56-70.

[KUZMINA, E. O. \& E. N. ANDREEVA] КУЗЬМИНА, Е.O., Е.Н. АНДРЕЕВА 2002. Структура сфагнового покрова Полистово-Ловатской болотной системы. - [The strusture of sphagnum cover of Polistovo-Lovatskaya bog system] В кн.: Природные и культурные ландиафты: проблемы экологии и устойчивого развития. Мат. Обществ.-науч. конф. с международным участием. Псков, 28-29 ноября 2002 г. Ч. 1. Псков [In: Prirodnye i kul'turnye landshafty: problemy ecologii $i$ ustojchevogo razvitiya.Materialy Obshchestvenno-nauchnoj konf. $c$ mezhdunarodnym uchastiem. Pskov, 28-29 November 2002. Ch.I. Pskov] : 85-88. /28 Sphagnum species are in the area, some species are cited (Pskov Province).

[KUZMINA, E.O. \& E.N. ANDREEVA] КУЗЬМИНА, Е.O., Е.Н. АНДРЕЕВА. 2002. Особенности распространения сфагновых мхов на северо-западе России. - [The peculiarity of distribution of peat mosses on north-west Russia] “[90-летие]”: 38-40.

[KUZMINA, E.О.] КУЗЬМИНА, Е.О. 2003. Флора листостебельных мхов Корякского нагорья. - [Flora of mosses of Koryakskoe Mountains] Aвтореферат ... канд. биол. наук., СПб [Ph. D. Thesis, Sankt-Petersburg] : 1-24. 
[KUZMINA, E.Yu.] КУЗЬМИНА, Е.Ю. 2001. Листостебельные мхи нарушенных и естественных местообитаний Варандейского и Торавейского нефтяных местораждений (Ненецкий автономный округ, Архангельская область). - [Mosses of disturbed and natural habitats in Varandejskij and Toravejskij petroleum mining areas (Nenetckij an independent district, Arkhangelsk range)] Новости сист. низи. pacm. [Novosti Sist. Nizch. Rast.] 35: 229-239.

[KUZMINA, E.Yu.] КУЗЬМИНА, Е.Ю. 2002. Таксономический анализ флоры листостебельных мхов Корякского нагорья. - [Taxonomical analize of moss flora of Koryakskoye Upland] "[90-летие]”: 36-38.

[KUZMINA, E.Yu. \& T.M. KOROLEVA] КУЗЬМИНА, Е.Ю., Т.М. КОРОЛЕВА 2001. Листостебельные мхи грядово-мочажинно-озерковых болот в верховьях р. Тромьеган (Западная Сибирь). - [Mosses of hummock-hollow-lake complex mires in upper course of Tromegan River (West Siberia)] Новости сист. низи. pacm. [Novosti Sist. Nizch. Rast.] 35: 239-247./ Annotated list of 43 mosses.

[LANTRATOVA, A.S., V.A. BAKALIN, P.N. LAPSHIN \& M.А. BOICHUK] ЛАНТРАTOBА, А.С., В.А. БАКАЛИН, П.Н. ЛАПШИН, М.А. БОЙЧУК. 2001. К флоре листостебельных мхов ботанического сада Петрозаводского Государственного Университета. - [On moss flora of Petrozavodsk University Botanical garden] Hoвости сист. низи. pacm. [Novosti Sist. Nizch. Rast.] 35: 249-258. Annotated list of 127 mosses.

LEIS, M. \& L. KANNUKENE 2001. The bryophytes of Vormsi Island. - Estonia Maritima 5: 77-106./ Annotated list of 229 species.

[LIKHACHEV, A.Yu. \& O.A. BELKINA] ЛИХАЧЕВ, А.Ю., О.А. БЕЛКИНА 2001. Сравнительный анализ флоры листостебельных мхов Полярно-альпийского ботанического сада-института (Мурманская область). - [Comparative analysis of moss flora of Polar-alpine botanical garden-institute (Murmanskaya region)] "Anamumbl-2001": 24-25.

[MAKSIMOV, А.І.] МАКСИМОВ, А.И.. 2001. Особенности флор листостебельных мхов охраняемых территорий Карелии. - [The peculiarity of moss floras of protection territories of Karelia] "Anamumb-2001": 26-27.

[MAKSIMOV, A.I. \& T.A. MAKSIMOVA] МАКСИМОВ, А.И., Т.А. МАКСИМОВА 2001. Интересные и редкие виды листостебельных мхов северного Приладожья. - [Interasting and rare moss species of north Priladozhya] Новости сист. низи. pacm. [Novosti Sist. Nizch. Rast.] 35: 258-265. The annotated list includes 47 rare mosses (northern Europaen Russia).

[MAKSIMOV, A.I. \& T.A. MAKSIMOVA] МАКСИМОВ, А.И., Т.А. МАКСИМОВА 2001. Листостебельные мхи - [Mosses] В кн: Инвентаризация и изучение биологического разнообразия на территории чентральной Карелии (ред Громцев, А.Н., В.И. Крутов) Петрозаводск, Карельский научный иентр РАН [In: Gromtcev, A.N. \& V.I. Krutov (eds.) Inventarizatsiya i izuchnie biologicheskogo raznoobrazia v tsentralnoi Karelii. Petrozavodsk, Karel'skij nauchnij tsentr RAN]: 94-101. List of 160 mosses (Karelia).

[MAKSIMOV, A.I. \& T.A. MAKSIMOVA] МАКСИМОВ,
А.И., Т.А. МАКСИМОВА 2002. Листостебельные мхи островов Белого моря. - [Mosses of the White Sea Islands] В кн.: Культурное и природное наследие островов Белого моря. Петрозаводск. (ред. И.Иико, H. Михайлова) [In: Ieshko, E \& N. Mikhailova (eds.) Natural and Cultural Heritage of the White Sea Islands. Customer: Karelian Research Centre of RAS. Petrozavodsk.]: 97-101.

[ MAKSIMOV, A.I. \& M.G. NAPREENKO] МАКСИМОВ, А.И., М.Г. НАПРЕЕНКО 2001. О распространении Sphagnum molle (Sphagnaceae) в России. - [On distribution of Sphagnum molle (Sphagnaceae) in Russia] Бот. Журн. [Bot. Zhurn.] 86 (10): 96-99.

[MAKSIMOV, A.I.] МАКСИМОВ, А.И. 2002. Редкие виды мхов Карелии, находящиеся на границе ареала. - [Rare mosses occurring on their distribution boundary in Karelia] “[90-летие]”: 40-41.

[MALYSHEVA, T.V.] МАЛЫШЕВА, Т.В. 2002. Сохранение бриологической (и биологической в целом) информации для обеспечения перманентности мониторинга окружающей среды и фитоценозов. - [Conservation bryologycal (and biological as a whole) information for maintenance of permanence of monitoring of environment and phytocoenoses] "[90-летие]": 42-43.

[MAJEVSKA, S.M.] МАЄВСЬКА C.M. 2001. Морфофізіологічні аспекти стійкості мохів до токсичної дії іонів важких металів. - [Morpho-physiological aspects of moss resistence to the toxic effects of heavy metals] Автореферат ... канд. биол. наук, Львів [Ph. D. Thesis, Lviv] : 1-20.

[MASLOVSKIJ, O.M.] МАСЛОВСКИЙ, О.м. 2002. Эколого-географические особенности бриофлоры Беларуси в системе бриофлор Восточной Европы и вопросы охраны мохообразных. - [Ecologicalgeographical features of Belarus bryoflora in system of bryofloras of East Europe and questions of protection of bryophytes] "[90-летие]": 43-45.

[MEL'NIKOVA, E.V.] МЕЛЬНИКОВА, Е.В. 2001. Зеленые мхи Северо-Западного Кавказа и Предкавказья. - [Mosses of North-West Caucasus and Cis-Caucasus] Автореферат ... канд. биол. наук., Краснодар [Ph. D. Thesis, Krasnodar] : 1-19.

MINAMI, Yo., S. OKITSU, H. KANDA, V.Ya. CHERDANTSEVA \& S.Yu. GRISHIN. 2001. Occurrence of bryophytes on Paramushir Island, northern Kuriles, Far East Russia. - Mem. Nat. Inst. Polar Res., Special Issue. 54: 487-493. The most common bryophytes of Paramushir Island are listed.

[MULDIYAROV, E.Ya., E.D. LAPSHINA \& A.L. BORISENKO] МУЛЬДИЯРОВ, Е.Я., Е.Д. ЛАПШИНА, А.Л. БОРИСЕНКО 2000. Бриофлора лесных болот Западной Сибири. - [The bryoflora of forest bogs of West Siberia] В кн.: Проблемы изучения растительного покрова Сибири: Тезисы докладов II Российской научной конференции, посвященной 150-летию со дня рождения П.Н. Крылова (Томск, 24-26 апреля 2000 г.) Томск: Изд-во ТГУ [In: Problemy izucheniya rastitel' nogo pokrova Sibiri: Tezisy dokladov II Rossijskoj nauchnoj konferencii, pocvyashchennoj 150letiju so dnya rozhdeniya P.N. Krylova (Tomsk, 24-26 April 2000) Tomsk: izd-vo TGU]: 88-89. / The bryoflora of forest bogs of West Siberia includes 126 species. Some 
species are listed.

[MULDIYAROV, E. YA. \& N. A. CHERNOVA] МУЛЬДИЯРОВ, Е. Я., Н. А. ЧЕРНОВА 2003 '2002'. Новые виды мохообразных Томской области. - [New records of bryophytes in Tomsk Province] Arctoa 11: 215-218.

[NEDOSPASOVA, N.V.] НЕДОСПАСОВA, Н.В 2001.Редкие виды печеночников Псковской области. - [Rare liverworts on Pskov Region] В кн.: СевероЗапад России: взаимодействие общества и природы. Мат. обществ.-научн. конф. с международным участи ем. Псков, 29-30 ноября 200 12. Ч. 2. Псков [In: SeveroZapad Rossii: vzaimodejstvie obshchestva $i$ prirody. Materialy obshchestvenno-nauchnoj konferencii $s$ mezhdunarodnym uchastiem. Pskov, 29-30 November 2001. Ch. 2. Pskov]: 95-97. / 27 species of liverworts are cited.

[NEDOSPASOVA, N.V.] НЕДОСПАСОВА, Н.В. 2002. Мохообразные окрестностей озера Елизароваское. [The bryophytes of Elizarovskoe Lake surroundings] Природа Псковского края. N 14. СПб [Priroda Pskovskogo Kraya, N 14. Sankt-Petersburg]: 7-12./ List of 27 liverworts and 87 mosses (Pskov Province).

[NESHATAEVA V.Yu. \& I.V. CZERNYADJEVA] HEШАТАЕВА В.Ю., И.В. ЧЕРНЯДЬЕВА. 2001. Геоботаническая и бриофлористическая характеристика окрестностей озера Вонтынглор. - [Geobotanical and bryofloristical characteristics of vicinity of Vontynglor Lake] В кн.: Биологические ресурсы и природопользование. Bыn. 4. Cyргуm [In: Biologicheskie resursy $i$ prirodopol'zovanie. Vyp. 4. Surgut]: 51-75. / List of 75 bryophythes (Middle Ob River, West Siberia).

[NESHATAEVA V.Yu., D.E. GIMEL'BRANT, E.S. KUZNETSOVA \& I.V. CZERNYADJEVA] HEШAТАЕВА В.Ю., Д.Е. ГИМЕЛЬБРАНТ, Е.С. КУЗНЕЦОВА, И.В. ЧЕРНЯДЬЕВА. 2002. Коренные старовозрастные каменноберезовые леса юго-западной Камчатки. - [Virgin old-growth stone-birch forests of Kamchatka] В кн.: Сохранение биоразнообразия Камчатки и прилегающих морей. Мат. III науч. конф. 27 28 ноября 2002 г. Петропавловск-Камчатский [In: Conservation of biodiversity of Kamchatka and coastal waters. Materials of III scientific conference. Petropavlovsk-Kamchatsky, 27-28 November 2002]: 6973. Ca. 40 species of mosses occur in old-growth Betula lanata forests in Kamchatka; some species are cited.

[NESHATAEVA V.Yu., D.E. GIMEL'BRANT, E.S. KUZNETSOVA \& I.V. CZERNYADJEVA] HEШAТАЕВА В.Ю., Д.Е. ГИМЕЛЬБРАНТ, Е.С. КУЗНЕЦОВА, И.В. ЧЕРНЯДЬЕВА. 2003. Ценотические, бриофлористические и лихенобиотические особенности коренных старовозрастных каменноберезовых лесов юго-западной Камчатки. - [The species composition of vascular plants, mosses and lichens and the community structure features of pristine old-growth stone-birch forests of south-west Kamchatka] $B$ кн.: Сохранение биоразнообразия Камчатки и прилегающих морей. Доклады ІІІ научной конф. 26-27 ноября 2002 г. Петропавловск-Камчатский [In:Conservation of biodiversity of Kamchatka and coastal waters. Proc. III scientific conference, Petropavlovsk-Kamchatsky, November 26-27, 2002]: 100-123. / List of 69 bryophytes and bryoflora analysis.

[NOTOV, A.A. \& U.N. SPIRINA] HOTOB, A.A., У.H.
СПИРИНА. 2002. О проблеме ботанико-географического анализа бриофлоры центра и северо-запада Русской Равнины. - [On the problem of phytogeographycal analysis of bryoflora of central and north-west Russian Plain] "[90-летие]": 45-46.

[NOTOV, A.A. \& U.N. SPIRINA] HOTOB, A.A., У.H. СПИРИНА. 2003. Новые данные к бриофлоре Тверской области. - [New data on the bryoflora of Tver' Province] B кн.: Ботанические исследования в Тверском регионе: Сб. науч. тр. Bыn. 1 (ред. Нотов А.А. ). Tверь: OOO «TEPC».[In: Notov A.A. Botanicheskie issledovaniya v Tverskom regione: Sbornik nauchnyh trudov. Vyp. I. Tver', OOO “GERS”]: 20-32/39 mosses and 7 liverworts are reported as new for province.

[NOTOV, A. A., U. N. SPIRINA, E. A. IGNATOVA \& M. S. IGNATOV] HOTOB, А. А., У. Н. СПИРИНА, Е. А. ИГНАТОВА, М. С. ИГНАТОВ 2003 '2002'. Листостебельные мхи Тверской области (Средняя полоса Европейской России). - [Mosses of the Tver Province (Middle part of European Russia)] Arctoa 11: 297-332.

[NOZHINKOV, A.E.] НОжИНкОВ А.Е. 2001. Зеленые мхи г. Барнаула. - [Mosses of Barnaul Sity] $B$ кн.: Флора и растительность Сибири и Дальнего Востока. Чтения памяти Л..М. Черепнина: Материалы III Российской конф. Красноярск: КГПУ. [In: Flora $i$ rastitel'nost' Sibiri i Dal'nego Vostoka. Chteniya pamyati L.M. Cherepnina: Materialy III Rossijskoj konferencii. Krasnoyarsk: KGPU] : 70-71. /33 species are cited.

[NOZHINKOV, A.E.] НОЖИНКОВ А.Е. 2002. Зеленые мхи Бащелакского заказника. - [Mosses of Baschalkskiy Reserve] В кн.: Проблемы ботаники Южной Сибири и Монголии. Тез. докл. Первой межд. научнопрактической конф. Барнаул, 26-28 ноября 2002 г. Барнаул [In: Problemy botaniki Yuzhnoj Sibiri $i$ Mongolii.Tezisy dokladov Pervoj mezhdunarodnoj nauchno-prakticheskoj konferencii. Barnaul, 26-28 November 2002. Barnaul]: 19-20. / Moss flora of the Reserve includes 54 species. Some species are cited (Altai).

[NOZHINKOV, A.E.] НОЖИНков А.Е. 2002. Зеленые мхи окрестностей крупных городов лесостепной зоны Алтайского края. - [Mosses of cities' surroundings of forest-steppe zone of Altay Territory] $B \kappa \mu$.: Антропогенное воздействие на лесные экосистемы: Тез. док. II Международной конф. (18-19 апреля 2002 г., Барнаул) Барнаул: Изд-во Алт. ун-та.[In: Antropogennoe vozdejstvie na lesnye ekosistemy: Tezisy dokladov II Mezhdunarodnoj konferencii (18-19 April 2002, Barnaul) Barnaul:Izd-vo Altajckogo universiteta]: 64-66. The moss flora of Bijsk and Barnaul Cities includes 53 species. Some species are cited.

[NOZHINKOV, A.E.] НОЖИНКОВ А.Е. 2002. Бриевые мхи равнинной части Алтайского Края. - [Mosses of plain part of Altaj Region] "[90-летие]”: 45-46.

[OВ'EDKOVA, S.I.] ОБЬЕДКОВА, С.И. 2003. Моховидные национального парка "Орловское Полесье". - [Mosses of the National Park "Orlovskij Poles'e"] "[ХІ съезд РБО]": 209-210.

OTNYUKOVA, T. N. 2001. A new species of Orthotrichum (Orthotrichaceae, Musci) from Tuva Republic, South Siberia. - Arctoa 10: 155-156.

OTNYUKOVA, T. N. 2001. Notes on Dicranum (Dicranaceae, 
Musci) in Russia.1.Dicranum nipponense found in Far East. - Arctoa 10: 157-160.

OTNYUKOVA, T. N. 2003 '2002'. A study of the Didymodon species (Pottiaceae, Musci) in Russia. I. Species with caducous leaf apices - Arctoa 11: 337-349.

[OTNYKOVA, T.N.] ОтНЮКОВА, T.H. 2003. Морфология и экология Dicranum bergeri Bland. (Musci, Dicranaceae) в Сибири. - [Morphology and ecology Dicranum bergeri Bland. (Musci, Dicranaceae) in Siberia] “[ХI съезд РБО]": 210-212.

PISARENKO, O. Yu., E. A. IGNATOVA \& M.S. IGNATOV 2001. Entostodon hungaricus (Boros) Loeske (Funariaceae, Musci) in Altaisky Territory, South Siberia. Arctoa 10: 97-102.

[PISARENKO, O. Yu.] ПИСАРЕНКО О.Ю. 2001. Мохообразные в растительном покрове Сибири: подходы к изучению и возможности использования бриологических данных. - [Bryophytes in the plant cover of Siberia: investigation approaches and opportunites of use of bryological data] В кн.: Исследования молодых ботаников Сибири. Сборник докладов молодежной конф. Новосибирск. [In: Researches of young Siberian botanists. Proc. Youth conf. Nowosibirsk]: 40-46.

[PISARENKO, O. Yu.] ПИСАРЕНКО, О.Ю. 2001. Эпифитные и эпиксильные бриосообщества в черневых лесах Салаира. - [Epiphytic and epixilic bryophyte communities in Salair tall-herbaceous fir-aspen forests] Krylovia 3(1): 65-77. $/ 9$ epiphytic and epixilic bryophyte communities are described.

[PISARENKO, О. Yu.] ПИСАРЕНКО, О.Ю. 2001. Мохообразные. - [Bryophytes] В кн: Флора и растительность Катунского заповедника (Горньй Алтай) (ред. В.П. Седельников). Новосибирск [In: Sedelnikov, V.P. Flora and vegetation of Katunskii preserve (Altai mountainous). Nowosibirsk]: 206-227. / Annotated list of 215 mosses.

[PISARENKO, O. Yu.] ПИСАРЕНКО О.Ю. 2002. Эколого-ценотическое распределение мхов в растительности Катунского заповедника. - [Ecological and coenonotic distribution of mosses in Katunskii reserve vegetation]. $B$ кн: Проблемы ботаники Южной Сибири и Монголии. Тезисы докладов Первой международной научно-практической конференци. (26-28 ноября 2002 г., Барнаул). Барнаул [In: Problemy botaniki Juzhnoj Sibiri $i$ Mongolii.Tezisy dokladov Pervoj mezhdunarodnoj nauchno-prakticheskoj konferencii. (Barnaul, 26-28 November 2002). Barnaul]: 65-66. / Some mosses are cited.

PISARENKO, O. Yu., E. A. IGNATOVA, M. S. IGNATOV 2001. Entosthodon hungaricus (Boros) Loeske (Funariaceae, Musci) in Altaisky Territory, South Siberia. - Arctoa 10: 97-102.

[PISARENKO, O. Yu. \& G. S. TARAN] ПИСАРЕНКО, О.Ю., Г.С. ТАРАН. 2001. Мохообразные Елизаровского заказника (нижняя Обь) - [Bryophytes of Elizarovskij Reserve (Lower Ob River)] Krylovia 3 (2): 88-98. Annotated list of 90 mosses and 10 liverworts.

[POPOV, S.YU., S. A. MOSHKOVSKY, K. I. BELOVEZHETS, T. S. CHUPALENKOVA, N. L. MELNICHENKO, M. S. IGNATOV] ПOПOB, C.Ю., С. А. МОШКОВСКИЙ, Л. И. БЕЛОВЕЖЕЦ, Т. С ЧУПАЛЕНКОВА, Н. Л. МЕЛЬНИЧЕНКО, М. С. ИГНАТОВ 2001. Материалы по бриологической экспедиции по госу- дарственному природному заповеднику “Присурский”. - [Contributions from the bryological expedition in the State Nature Reserve "Prisursky"] Экологический вестник Республики Чувашия [Ecologichesky Vestnik Respubliki Chuvashiya] 25: 29-34.

[POPOVA, N.N.] ПОПОВА, Н.Н. 2002. Некоторые методологические подходы к анализу региональных бриофлор. - [Some methodological approaches to analysis of regional bryofloras] "[90-летие]": 48-49.

[POPOVA, N.N. \& S.I. DYAGTEVA] ПОПОВA, H.H., С.И. ДЕГТЯРЕВА. 2003. О некоторых количественных параметрах мохового компонента лесостепных дубрав. - [About some quantitative parameters of a moss component of forest-steppes of ouk-woods] "[XI съезд РБО]": 212-213.

[POPOVA, N. N.] ПОПОВА, Н. Н. 2003 '2002'. Бриофлоpa Среднерусской возвышенности. I. - [Bryoflora of the Central Russian Upland. I] Arctoa 11: 101-168.

[POPOVA, N.N. \& T.S. MACAJ] ПОПОВА, Н.H., Т.C. МАЦАЙ 2003. Ценотическая роль мхов в кальцефитно-петрофитных степях Среднерусской возвышенности. - [Coenotical role of mosses in carbonate-petrous steppes of Central Russian Upland] "[ХІ съезд РБО]": 213-214.

[POTEMKIN, A.D.] ПОТЕМКИН, А.Д. 2001. Эволюция, филогения и классификация семейства Scapaniaceae (Hepaticae). - [Evolition, phylogeny and classification of Family Scapaniaceae (Hepaticae)] Aвmopeф. дисс. на соиск. ... д.б.н., СПб. [Doctorial Thesis, SanktPetersburg]: $1-36$.

[POTEMKIN, A.D.] ПОТЕМКИН, А.Д. 2002. Флора как явление и как процесс: взгляд на задачи исследования флоры мохообразных. - [The flora as a phenomenon and a process: a view on tasks of bryophyte flora investigation] "[90-летие]": 49-51.

[POTEMKIN, A.D.] ПОТЕМКИН, А.Д. 2002. Проблема дифференциации физиономически сходных видов мохообразных и некоторые подходы к ее решению. - [The problem of differentiation of species, which are similar in their habit, and some approaches to its solution] "[90-летие]": 51-53.

[POTEMKIN, A.D.] ПОТЕМКИН, А.Д. 2002. Эволюция периантия видов рода Scapania и некоторые закономерности эволюции периантия печеночников. - [On the perianth evolution in the species of the genus Scapania and some regularities in evolition of perianth in hepatics] “[90-летие]": 53-56.

[POTEMKIN, A.D.] ПОТЕМКИН, А.Д. 2002. К флоре печеночных мхов бассейна реки Рагуши и прилежащих территорий (Ленинградская и Новгородская области). - [On the liverwort and hornwort flora of the River Ragusha Basin and adjacent territories (Leningrad and Novgorod Provinces)] Новости сист. низи. pacm. [Novosti Sist. Nizch. Rast.] 36: 244-253. Annotated list of 53 species.

[POTEMKIN, A.D.]ПОТЕМКИН, А.Д. 2002. Phylogenetic system and classification of the family Scapaniaceae Mig. emend. Potemkin (Hepaticae). - Ann. Bot. Fennici 39(4): 309-334.

[POTEMKIN, A.D.] ПОТЕМКИН, А.Д. 2003. К вопросу о путях эволюции и объеме семейств Jungermanniaceae 
и Lophoziaceae (Hepaticae). - [On the paths of evolution and the volume of the families Jungermanniaceae и Lophoziaceae] "[ХІ съезд РБО]": 214-216.

[POTEMKIN, A.D.] ПОТЕМКИН, А.Д. 2003. Анна Леонидовна Жукова (к 70-летию со дня рождения). [Anna Leonidovna Zhukova (towards $70^{\text {th }}$ birthday)] Бот. Журн. [Bot. Zhurn] 88(7): 142-146.

[POTEMKIN, A.D.] ПОТЕМКИН, А. Д. 2003. Международное совещание Проблемы бриологии на рубеже веков”, посвященное 90-летию со дня рождения Р.Н. Шлякова и И.И. Абрамова (Санкт-Петербург, 4-6 ноября 2002). - “[ХІ съезд РБО]” Бот. Журн. [Bot. Zhurn] 88(8): 139-143.

[POTEMKIN, A.D. \& V.M. KOTKOVA] ПОТЕМКИН, А.Д., В.М. КОТКОВА. 2003. Печеночники музея-заповедника "Парк Монрепо" (г. Выборг, Ленинградская область). - [Liverworts of the museum and reserve "Park of Monrepos" (town of Vyborg, Leningrad Province)] Бот. Журн. [Bot. Zhurn] 88(3): 37-44.

RAZGULYAEVA, L. V., M. G. NAPREENKO, CH. WOLFRAM \& M. S. IGNATOV 2001. Campylopus introflexus (Dicranaceae, Musci) - an addition to the moss flora of Russia. - Arctoa 10: 185-188.

[RYKOVSKY, G.F.\& O.M. MASLOVSKIJ] РЫKOBCКИЙ, Г.Ф., О.М. МАСЛОВСКИЙ 2002. Флора печеночников Беларуси (таксономия, экология, география). - [Liverwort flora of Belarus (taxonomy, ecology, geography)] "[90-летие]”: 56-57.

SALMINA, L. 2002. Sünu Ricciocarpos natans L. un Odontoschisma sphagni (Dicks.) Dum. sastopamîba Latvijâ - [Hepatics Ricciocarpos natans L. and Odontoschisma sphagni (Dicks.) Dum. in Latvia] Retie augi. Rîga: 107-112.

SAMIGULLIN,T.KH., S.P.YACENTYUK, G.V.DEGTYARYEVA, K.M.VALIEHO-ROMAN, V.K.BOBROVA, I.CAPESIUS, W.F.MARTIN, A.V.TROITSKY, V.R.FILIN, A.S.ANTONOV 2003 '2002'. Paraphyly of bryophytes and close relationship of hornworts and vascular plants inferred from chloroplast rDNA spacers sequence analysis. - Arctoa 11: 31-43.

[SAVEL'EVA, N.A.] САВЕЛЬЕВА, Н.А. 2001. Бриофлора и структура бриосинузий Ильменского государственного заповедника (Южный Урал). - [Bryoflora and bryosinuziya structure of Il'menskij State Reserve (South Ural)] Автореферат ... канд. биол. наук., Екатеринбург [Ph. D. Thesis, Ekaterinburg] : 1-24.

[SEREDNYAK, A.A.] СЕРЕДНЯК, А.А. 2002. Бриофлористические исследования лесного массива Бузулукский Бор. - [Bryofloristical research of the forest "Buzuluksky Bor"] "[90-летие]”: 58-59.

[SERGEEVA, V.V.] CЕРГЕЕВA, В.В. 2003. Экологический анализ флоры зеленых мхов северо-западного Кавказа и Предкавказья. - [Ecologycal analysis of moss flora of north-east Caucasus and Cis-Caucasus] “[ХI съезд РБО]”: 216-217.

[SERGEEVA, V.V. \& A.S. PORODENKO] CEPTEEBA, В.В., А.С. ПОРОДЕНКО 2003. Мохообразные экстремальных мест произрастания Краснодарского края. - [Bryophyta of extreme habitats of Krasnodar Territory] "[ХІ съезд РБО]": 217-218.
[SEREDA, V.A. \& V.V. FEDYAEVA] CЕРЕДА, В.A., В.В. ФЕДЯЕВА. 2003. Экологическая приуроченность мохообразных лесопарковыой зоны г. Ростова-на Дону. - [Habitat distribution of bryophytes of the forestpark zone of Rostov-na-Donu City] "[ХІ съезд РБО]": 218-220.

[SHESTAKOVA, A.A.] ШЕСТАКОВА, А.А. 2002. Таксономический анализ флоры листостебельных мхов Нижегородской области. - [Taxonomical analize of moss flora of Nizhegorodsky Region] "[90-летие]”: 69-70.

[SHESTAKOVA, A.A. \& O.A. ZAPLIENKO] ШECTAКОВА, А.А., О.А. ЦАПЛИЕНКО 2003. Флора листостебельных мхов города Нижнего Новгорода. - [Moss flora of Nizhnij Novgorod City] "[XI съезд РБО]": 222-224.

[SHKHAGAPSOEV, S.H. \& Z.H. HARZINOV] ШХАГАПCOЕВ, С.Х., 3.Х. ХАРЗИНОВ. 2003. Бриофлора лесных экосистем Кабардино-Балкарии (Центральный Кавказ). - [Bryoflora of forest ecosystems of Kabardino-Balkaria (Central Caucasus)] “[ХІ съезд РБО]” : 224-225.

[SHUBINA, T.P. \& G.V. ZHELEZNOVA] ШУБИНА, Т.П., Г.В. ЖЕЛЕЗНОВА. 1999. Флористический состав листостебельных мхов болот Мезенско-Вычегодской равнины. - [The moss floristic composition of the bogs of the Mezensko-Vychegodskij plain] $В$ кн.: Болота и заболоченные леса в свете задач устойчивого природопользования. Мат. Совещания. Москва. [In: Bolota $i$ zabolochennye lesa v svete zadach ustoichevogo prirodopolzovania. Proc, conf,, Moscow]: 161-163. /The flora of bogs included 68 mosses. Some species are cited.

[SHUBINA, T. P. \& G. V. ZHELEZNOVA] ШУБИНА, Т. П., Г.В. ЖЕЛЕЗНОВА 2002. Листостебельные мхи равнинной части средней тайги европейского севеpo-востока. - [Mosses of plain part of middle taiga of European north-east] Eкатеринбург, урО РАH [Ekatarinburg, $\operatorname{UrO} R A N]$ : 1-157. / Annotated list of 210 species, and analyis of bryoflora.

[SIROTINA, I.V.] СИРОТИНА, И.В. 2002. Своеобразие бриофлоры северо-западного Копетдага. - [Peculiarity of bryoflora of northwest Kopetdag] "[90-летие]": 59-60.

[SMAGIN, V.A. \& M.S. ВОТСН] СМАГИН, В.А., М.С. БОЧ 2001. Флора и растительность болот Европейского Севера России (в пределах таежной зоны). [Flora and vegetation of mires in the Russian North (within taiga region)] Бот. Журн. [Bot. Zhurn] 86(6): 40-55. The flora of mires included 84 mosses and 16 liverworts; some species are cited.

[SOFRONOVA, E. V.] СОФРОНОВА, Е. В. 2003. К флоре печеночников среднего течения р. Лены. - [On hepatic flora of Middle Lena River] Maт. междунар. Саха-Финляндской конф., посв. 100-летию экспедиции А.К. Каяндера по реке Лене "Проблемы ботанических и лесоводственных исследований в Республике Саха (Якутия) и Финляндии. Якутск: ЯФ Изд-во CO PAH [Mat. mezhdun. Sakha-Finlyandskoj konf., posvyashchennoi 100-letiyu expedizii A. C. Cajandera po reke Lene "Problemy botanicheskikh $i$ lesovodstvennykh issledovanij v respublike Sakha (Yakutiya) $i$ Finlandii. Yakutsk, YF SO RAN]: 65-68.

[SOFRONOVA, E. V. \& E. I. IVANOVA] CОФРОНОВA, Е. В., Е. И. ИВАНОВА 2003. К изученности бриофло- 
ры ресурсного резервата “Чабда" (бассейн р. Май, Юго-Восточная Якутия). - [Studying of bryoflora of the resourse reserve «Chabda» (the Maya River Basin, South-East Yakutia)] Тр. 2 междунар. конф. "Роль мерзлотных экосистем в глобальном изменении климаma”. Якутск, ЯФ СО РАН [Proc. 2d Int. Conf. The role of permafrost ecosysstems in global Climate change. Yakutsk, Yak. fil. Sib. Otd. Russ. Akad. Nauk]: 323-329 (Russian version), 233-238 (English version).

[SOFRONOVA, E.V.] CОФРОНОВА, Е.В. 2002. Эколого-ценотическая характеристика печеночников в растительном покрове Восточного Верхоянья (Якутия). - [Ecological-coenological characteristics of liverworts in plant cover of Eastern Verhoyanje (Yakutiya)] "[90летие]": 60-61.

[SOFRONOVA, E. V.] СОФРОНОВА, Е. В. 2001. Новые находки редких видов печеночников в Якутии. - [New findings of rare liverworts in Yakutia] Arctoa 10: 201 205.

[SOFRONOVA, E.V.] CОФРОНОВA, Е.В. 2003. Печеночные мхи якутской части Восточного Верхоянья. - [Liverworts of Yakutiya part of East Verhoyanje] Автореферат ... канд. биол. наук., СПб [Ph. D. Thesis, Sankt-Petersburg]: 1-21.

[SPIRINA, U.N.] СПИРИНА, У.Н. 2002. Бриофлора Тверской области. - [Bryoflora of Tver' Region] Aвmорефеpaт ... канд. биол. наук., M. [Ph. D. Thesis, Moskow] : 1-18.

[SPIRINA, U.N.] СПИРИНА, У.Н. 2000. Анализ бриофлоры окрестностей села Большая Коша Селижаровского района Тверской области. - [Analysis of the bryoflora of Bolshaya Kosha surroundings in the Selizharovo District of Tver Province] Уч.зап.Тверск. Гос. Ун-та [Uchen. Zap. Tversk. Gos. Univ.]: [2000] 132-141.

[SPIRINA, U.N., E.A.YAGODKINA] СПИРИНА, У.Н., Е.А. ЯГОДКИНА. 2003. Итоги первичной интродукции мохообразных в Ботаническом саду ТвГУ. [Results primary introdaction bryophytes in a Botanic garden TvGUm] В кн: Ботанические исследования 6 Тверском регионе: Сб. науч. тр. Вып. 1 (ред. Нотов A.A.) Tверв: OOO «ГEPC» [In: Notov A.A. Botanicheskie issledovaniya v Tverskom regione: Sbornik nauchnyh trudov. Vyp. I. Tver', OOO “GERS”]: 77-85.

STECH, M., N.A. KONSTANTINOVA \& W. FREY 2002. Molecular divergence between Treubia Goebel and Apotreubia S.Hatt. \& Mizut., the two genera of the archaic liverwort class Treubiopsida (Hepaticophytina). - Nova Hedwigia 75(1-2): 91-100.

[SURAGINA, S.A.] СУРАГИНА, С.Ф. 2001. Листостебельные мхи Волгоградской области. - [Mosses of Volgograd Region] Автореферат ... канд. биол. наук., M. [Ph. D. Thesis, Moskow] : 1-23.

[SURAGINA, S. А.] СУРАГИНА, С. А. 2001. Листостебельные мхи Волгоградской области (Юго-Восток Европейской России). - [Mosses of Volgograd Province (South-Eastern European Russia)] Arctoa 10: 45-70.

[SURAGINA, S. A., E. A. IGNATOVA, M. S. IGNATOV \& V. I. ZOLOTOV] СУРАГИНА, С. А., Е. А. ИГНАТОВА, М. С. ИГНАТОВ, В. И. ЗОЛОТОВ 2003 '2002'. Материалы к флоре мхов Астраханской области (юг европейской России). - [Contribution to the Moss Flora of Astrakhan Province (South European Russia)] Arctoa
11: $169-174$.

SURAGINA, S. A., N. A. KONSTANTINOVA \& M. S. IGNATOV 2003 '2002'. Hepatics and Anthocerotae of the Volgograd Province. - Arctoa 11: 175-177.

TSEGMED, TS. 2001. Checklist and distribution of mosses in Mongolia. - Arctoa 10: 1-18.

[TSOGIIN, TS.] ЦЭГМЭД, Ц. 2001. Монгол орны ховд таних бичиг. - [Handbook of mosses of Mongolia] Улаанбаатар хот, Соёмбопринтинг [Ulaanbaatar, Sooemboprinting], $474 \mathrm{pp}$. (in Mongolian).

[TSEGMED, Ts.] ЦЭГМЭД, Ц. 2002. Неморальный элемент и реликтовые нахождения неморальных видов мхов в горных системах Монголии (Хангай, Хэнтэй, Монгольский Алтай). - [Nemoral element and relict findings of nemoral moss species in mountain systems of Mongolia (Hangaj, Hentej, Mongolian Altai)] "[90летие]": 63-65.

TSEGMED, TS. 2003 '2002'. The list of mosses of Bogdkhan National Park (Mongolia) - Arctoa 11: 219-228.

[TUBANOVA, D.Yа.] ТУБАНОВА, Д.Я. 2002. Состав и структура флоры листостебельных мхов северо-восточного Прибайкалья (на примере заповедника “Джергинский”). - [Composition and structure of moss flora of north-east Pribajkal'e (on example of Dzherginskij Reserve] Автореферат ... канд. биол. наук., Улан-Удэ. [Ph. D. Thesis, Ulan-Ude] : 1-19.

[TUBANOVA, D.Ya. \& O.A. ANENHONOV] ТУБАНOВА, Д.Я., О.А. АНЕНХОНОВ. 2003. Мхи высокогороий Джергинского заповедника (северо-восточное Прибайкалье). - [Mosses of higt altitude mountains of Dzherginski Reserve (north-east Pribajkal'e)] “[ХI съезд РБО]": 220-221.

[VASIL'EV, A.N. \& N.V. BELOVA] ВАСИЛЬЕВ, А.Н. Н.В. БЕЛОВА. 2003. Экологический анализ бриофлоры города Красноярска. - [Ecological analysis of bryoflora of Krasniyarsk Sity] “[ХІ съезд РБО]”: 200-201.

VELLAK, K., L. KANNUKENE, N. INGERPUU \& M. LEIS. 2001. Additions to the list of the Estonian bryophytes, 1997-2001. - Folia Cryptogamica Estonica 38: 71-78. Annotated list of 49 species.

[VIRCHENKO, B. M. \& L. A. BABENKO] ВIРЧЕНКО, В. М., Л. О. БАБЕНКО 2001. Знахідка Rhynchostegium rotundifolium (Brid. B.S.G. тa Myuroclada maximoviczii [sic!] (Borszcz.) Steere \& Schof. на сході Європи. [Finding of Rhynchostegium rotundifolium (Brid. B.S.G. and Myuroclada maximoviczii [sic!] (Borszcz.) Steere \& Schof. in the eastern Europe] Укр. бот. журн. [Ukr. Bot. Zhurn.] 58(1): 676-759.

[VORONOVA, O.G. \& V.L. SED'KO] BOPOHOBA, О.Г., В.Л. СЕДЬКО 2003. Видовое разнообразие зеленых мхов окрестностей биостанции “Озеро Кучак”. - [The species diversity of mosses of vicinity biostation "Kuchak Lake"] “[ХІ съезд РБО]”: 201.

WU YU-HUAN, GAO CHIEN \& B. C. TAN 2003 '2002'. The bryophytes of Gansu Province, China: a newly updated checklist. - Arctoa 11: 11-22.

[YAROSHEVICH, E.N. \& O.M. MASLOVSKIJ] ЯPOШЕВИЧ, Е.Н., О.М. МАСЛОВСКИЙ 2002. Инвентаризация бриологических коллекций СНГ и Европы с использованием компьютерной системы Herbarium 
(V.4). - [Inventory of bryologycal collections of CIS and Europe with use of computer system Herbarium (V.4)] "[90-летие]": 71-72.

[YATSENTYUK, S. P., N. A. KONSTANTINOVA, M. S. IGNATOV, J. HYVONEN, A. V. TROITSKY] ЯЦЕНТЮК, С. П., Н. А. КОНСТАНТИНОВА, М. С. ИГНАТОВ, Я. ХИВОНЕН, А. В. ТРОИЦКИЙ 2003. Изучение молекулярной филогении Jungermanniales путем анализа нуклеотидных последовательностей интрона гена trnL хлоропластной ДНК. - [Molecular phylogenetic study of Jungermanniales by analysis of chloroplast trnL intron sequences] Тезисы докл. ХI международного совещания по филогении растений. M., МГУ и др. [Abstr. XI soveshchaniya po filogenii rastenij. Moscow, Mosk. Gos. Univ.]: 117-118.

[ZAKHAROVA, V.I., N.S. KARPOV \& E.V. SOFRONOVA] ЗАХАРОВА, В.И., Н.С. КАРПОВ, Е.В. СОФРОНОВА. 2001. Восстановление растительности лесотундры после горных разработок в низовьях реки Яны (северная Якутия). - [Recovery of the foresttundra vegetation after gold-mining if the low Yana River (Northern Yakutia)] Бот. Журн. [Bot. Zhurn] 86(11): 121-127. Some mosses are cited.

[ZHELEZNOVA, G.V.] ЖЕЛЕЗНОВА, Г.В. 2000. Флора листостебельных мхов Республики Коми. - [Moss flora of the Komi Republic] Автореф. Әисс. на соиск. ... д.б.н., Сыктывкар.[Doctorial Thesis, Syktyvkar]: 1-48.

[ZHELEZNOVA, G.V. \& T.P. SHUBINA] ЖЕЛEЗHOBA, Г.В., Т.П.ШУБИНА. 2000. Мхи. - [Mosses] В кн.: Земля девственных лесов. Москва. [In: Zemlya devstvennyh lesov. Moscow]: 121-125. / The bryoflora of Pechoro-Ilych Reserve, Komi Republic includes 298 species.

ZHELEZNOVA, G.V.\& T.P. SHUBINA. 2000. Diversity of mosses in forest communities of the European NorthEast (The Komi Republic). - Biodiversity and Dynamics of Ecosystems in North Eurasia. BDENE. Vol. 2 (21-26 August, Novosibirsk, Russia): 252-253. / The moss flora of forest communities includes 274 species.

[ZHELEZNOVA, G.V. \& T.P. SHUBINA] ЖЕЛЕЗНОВА, Г.В., Т.П.ШУБИНА. 2000. Флора мхов антропогенно нарушенных территорий (Республика Коми). [Moss flora of the anthropogenic disturbed land (KOMI Republic)] В кн.: Освоение Севера и проблемы природовосстановления. Док. IV междунар. конф., Сыктывкар, Республика Коми, Россия, 3-7 августа 1998 г. Сыкmывкар. [In: Osvoenie Severa $i$ problemy prirodovosstanovleniya. Doclady IV mezdunarodnoj konf., Syktyvkar, KOMI Republic, Russia, 3-7 August 1998. Syktyvkar]: 213-219. The moss flora of anthropogenic disturbed land includes $19 \%$ of total flora.

[ZHELEZNOVA, G.V. \& T.P. SHUBINA] ЖЕЛE3HOВА, Г.В., Т.П.ШУБИНА. 2001. Мхи лиственных лесов. - [The mosses of hardwoof forests] Вкн.: Ценологическая и флористическая структура лиственных лесов европейского Севера ( ред. С.В. Дегтева). СПб, Наука.[In: Degteva, S. V. Cenologicheskaya i floristicheskaya struktura listvenny lesov evropejskogo Severa. Sankt-Petersburg, Nauka] : 173-215. /119 species from birch forest, 107 species from aspen forest and 71 species from alder forest are listed.

[ZHELEZNOVA, G.V. \& T.P. SHUBINA] ЖЕЛЕЗHOВА, Г.В., Т.П.ШУБИНА. 2001. Охраняемые виды мо- хообразных Республики Коми. - [Protected bryophytes of the Komi Republic] В кн.: Ботанические исследования на охраняемых природных территориях европейского северо-востока. Тр. Коми науч. центра УрО Ран. Сыктывкар. [In: Botanicheskie issledovaniya na ohranyaemyh prirodnyh territoriyah Evropejskogo Severo-Vostoka. Trudy Komi nauchnogo zhentra, Syktyvkar] 165: 200-207. / The bryoflora of Komi Republic include 175 rare mosses.

[ZHELEZNOVA, G.V. \& T.P. SHUBINA] ЖЕЛEЗHOВА, Г.В., Т.П.ШУБИНА. 2001. Долготные элементы в брофлоре Республки Коми. - [Geographic elements in bryoflora of the Komi Republic] $B$ кн.: Флора $u$ растительность Сибири и Дальнего Востока. Чтения памяти Л.М. Черепнна. Мат. ІІІ Российской конф. Красноярск, 23-27 апреля 2001 г. Красноярск [In: Flora i rastitelnost Sibiri i Dalnego Vostoka. Chteniya pamyati L.M. Cherepnina. Materialy III Rossijskoj konf. Krasnoyarsk, 23-27 April 2001]: 68-69. /Some species of different geographic elements are cited.

[ZHELEZNOVA, G.V., T.P. SHUBINA \& M.V. DULIN] ЖЕЛЕЗНОВА, Г.В., Т.П.ШУБИНА, М.В. ДУЛИН. 2001. Редкие бриофиты Европы на территории Республики КОМИ. - [Rare European Bryophyte species in the Komi Republic] "Anamumb-2001”: 15.

[ZHELEZNOVA, G.V., T.P. SHUBINA \& M.V. DULIN] ЖЕЛЕЗНОВА, Г.В., Т.П.ШУБИНА, М.В. ДУЛИН. 2002. Проблемы изучения бриофитов на особо охраняемых природных территориях республики Коми. [Problems of study of bryophytes in especially protection natural territories of Komi republic] "[90-летие]": 28.

[ZHELEZNOVA, G.V.\& T.P. SHUBINA] ЖЕЛEЗНОВА, Г.В., Т.П.ШУБИНА. 2002. Листостебельные мхи окрестностей оз. Пайхато (юго-западная часть о. Вайгач). - [Mosses of the vicinity of Pajhato Lake (the south-western part of the Island Vaygach)] В кн.: Экологическая ботаника: наука, образование, прикладные аспекты. Межд. Науч. Конф., посвященная 25-летию кафедры ботаники Сыктывкарского университета (1821 сентября 2002 года) Сыктывкар [Ecological botany: science, education, applying aspects. Abstracts of reports of international scientific conference, devoted to 25anniversary of botany department, Syktyvkar State University (18-21 September 2002). Syktyvkar]: 99-100. / The moss flora includes 81 species, some are cited. North of European Russia.

[ZHURBENKO, M.P., I.V. CZERNYADJEVA \& Yu.P. KOZHEVNIKOV] ЖУРБЕНКО М.П., И.В. ЧЕРНЯДЬЕВА, Ю.П. КОЖЕВНИКОВ. 2002. Лишайники, лихенофильные грибы, мхи и сосудистые растения острова Самойловский (Усть-Ленский заповедник, Арктическая Якутия. - [Lichens, lichenicolous fungi, mosses and vascular plants of Samoilovskii Island (UstLenskii Reserve, Arctic Yakytiya)] Новости сист. низи. pacm. [Novosti Sist. Nizch. Rast.] 36: 100-113. /Annotated list includes 72 mosses.

[ZOLOTOV, V. І.] ЗОЛОтОВ В. И. 2003. Bryaceae. - В кн.: Игнатов М.С., Е.А.Игнатова, Флора мхов средней части европейской России. Том 1. Sphagnaceae Hedwigiaceae. M., KMK [In: Ignatov, M.S. \& E. A. Ignatova, Moss flora of the Middle European Russia. Vol. 1. Sphagnaceae-Hedwigiaceae. Moscow, KMK]: 456-513. 
ZOLOTOV, V. I. \& M. S. IGNATOV 2001. On the axillary hairs of Leptobryum (Meesiaceae, Musci) and some other acrocarpous mosses. - Arctoa 10: 189-200.

[ZOLOTOV, V. I., M. S. IGNATOV, E. A. IGANTOVA \& N. N. РОРОVА] ЗОЛОТОВ, В. И., М. С. ИГНАТОВ, Е. А. ИГНАТОВА, Н. Н. ПОПОВА 2001. Мохообразные Зоринского участка Центрально-Черноземного заповедника. - [Bryophytes of Zorino branch of ZentralnoCzernozemny Reserve] Тр. Центрально-Черноземного гос. заповедника [Trudy Centralno-Czernozemnogo Gos. Zapovednika] 17: 85-95.

КРАСНЫЕ КНИГИ - RED DATA ВОOКS

[BAISHEVA, E.Z.] БАИШЕВА, Э.3. 2002. Мохообразные - [Bryophyta] В кн.: Красная книга республики Башкортостан. Т. 2. Мохообразные, водоросли, лишайники и грибы. Уфа, Изд-во Табигат [In: Red Data Book of the Bashkortostan Republic. Vol. 2. Brtophytes, algae, lichens and fungi. Ufa, Tabigat]: 17-44. Sphagnum subnitens, S. platyphyllum, S. lindbergii, Pyramidula tetragona, Weissia squarrosa, Dicranum viride, Plagiomnium confertidens, Paludella squarrosa, Timmia megapolitana, Orthotrichum pallens, Fabronia ciliaris, Cyrto-hypnum minutulum, Conardia compacta, Hamatocaulis vernicosus, Rhynchostegium murale, Rhynchostegium riparioides, Brachythecium geheebii, Entodon schleicheri, E. concinnus, Pylaisiella selwynii, Herzogiella seligeri, Frullania bolanderi, Riccia frostii.

[BARDUNOV, L. V., S. G. KAZANOVSKY, E. I. KOSOVICH, D. YA TUBANOVA, J. ENGEL] БАРДУНОВ, Л. В., С. Г. КАЗАНОВСКИЙ, Е. И. КОСОВИЧ, Д. Я, ТУБАНОВА, Д. Д. ЭНГЕЛ 2002. Моховидные. [Bryophyta] В кн.: Красная книга республики Бурятия: редкие и исчезающие виды растений и грибов, 2-е изд. Новосибирск, Наука [In: Red Data Book of Republic Buryatiya: rare and endangered species of plants and fungi. 2d ed. Novosibirsk, Nauka]: 209-254.

Бардунов: Mielichhoferia macrocarpa, $M$. mielichhoferiana, Conardia compacta, Voitia nivalis, Aongstroemiopsis julacea, Forsstroemia noguchii, Amblyodon dealbatus, Rhizomnium andrewsianum, Tetrodontium brownianum, Physcomitrium sphaericum, $P$. eurystomum; Бардунов, Казановский: Buxbaumia minakatae, Struckia argentata ssp. zerovii, Fissidens adianthoides; Бардунов, Тубанова: Jaffueliobryum latifolium, Oreas martiana, Neckera borealis; Казановский: Anomodon rugelii, Brachythecium buchananii, Pylaisiadelpha tenuirostris, Pseudoleskea incurvata, Mnium heterophyllum, Plagiomnium acutum, Bryohaplocladium angustifolium, Calycularia laxa, Marsupella alpina, Scapania sphaerifera, Cephalozia lacinulata, Lophozia obtusa; Казановский, Косович: Anomodon attenuatus, Riccia glauca; Косович: Hamatocaulis lapponicus, Sphagnum aongstroemii; Косович, Бардунов, Тубанова: Tomentypnum falcifolium; Тубанова, Бардунов: Indusiella thianschanica, Didymodon perobtusus; Энгел, Косович: Porella gracillima.

[IGNATOV, M. S.] ИГНАТОВ, М. C. 2001. Мохообразные. - [Bryophyta] В кн.: Красная книга города Москвы. Правительство Москвы [In: Red Data Book of Moscow City. Moscow Gouvernment]: 543-567. Warnstorfia exannulata, Anomodon longifolius, A. attenuatus, Rhynchostegium murale, Rhodobryum roseum,
Hylocomiastrum pyrenaicum, Ptilium crista-castrensis, Dicranella cerviculata, Dicranum bonjeanii, D. viride, $D$. polysetum, Lepidozia reptans, Metzgeria furcata, Plagiomnium undulatum, Homalia trichomanoides, Orthotrichum speciosum, Plagiothecium latebricola, Atrichum flavisetum, Syntrichia ruralis, Radula complanata, Seligeria pusilla, Sphagnum fimbriatum, S. magellanicum, S. fallax, S. subsecundum, Jamesoniella autumnalis.

[MULDIYAROV, E.Ya., E.D. LAPSHINA \& A.L. BORISENKO] МУЛЬДИЯРОВ, Е.Я., Е.Д. ЛАПШИНА, А.Л. БОРИСЕНКО. 2002. Мохообразные [Bryophyta] В кн.: Красная книга Томской области. Томск: Изд-во ТГУ [In: Red book of Tomsk Province. Tomsk, Izd-vo TGU]: 183-205. / Bryum weigelii, Dichelyma falcatum, Neckera pennata, Pterygoneuron subsessile, Aloina rigida, Scorpidium scorpioides.

[POPOVA, N. N.] ПОПОВА, Н. Н. 2001. Моховидные. [Bryophyta] В кн.: Красная книга Курской области. T. 2. Редкие и исчезающие виды растений и грибов. Тула, Центрально-Черноземный государственный природный биосферный заповедник и др. [Red Data Book of Kursk Province. Vol. 2. Rare and endangeded plants and fungi. Tula, Centralno-Czernozemnyj Gos. Prir. Biospher. Zapovednik \& al.]: 21-45. / Leiocolea badensis, Lophozia excisa, Lepidozia reptans, Riccia ciliata, Ricciocarpus natans, Anthoceros punctatus, Calliergon stramineum, Hamatocaulis vernicosus, Hygrohypnum luridum, Anomodon viticulosus, Tomentypnum nitens, Rhodobryum roseum, Dicranum viride, Orthodicranum strictum, Paraleucobryum longifolium, Hedwigia ciliata, Helodium blandowii, Hypnum vaucheri, Leucodon sciuroides, Meesia triquetra, Pseudobryum cinclidioides, Neckera pennata, Acaulon muticum, Aloina rigida, Tortella tortuosa, Tortula caninervis, Seligeria calcarea, Sphagnum contortum, S. fuscum, S. magellanicum, S. papillosum, S. russowii, $S$. wulfianum.

[RADZHI, A.D.] РАДЖИ, А.Д. 1998. Моховидные. [Bryophytes] B кн.: Красная книга Республики Дагестан. Редкие, находящиеся под угрозой исчезновения виды животных и рстений. Махачкала, Дагестанское книжное издательство [In: Red book of Dagestan. Rare and endangered species of animal and plants. Makhachkala, Dagestanskoe Knizhnoe Izd.]: 191-194. Indusiella thianschanica, Lindbergia brachyptera, Oreas martiana, Sphagnum squarrosum.[VASILIEV, A. N.] ВАСИЛЬЕВ, А. Н. 1999. Моховидные. - [Bryophyta] В кн.: Красная книга республики Тыва: растения. Новосибирск, Изд-во СО РАH [In: Red data book of the Tyva Republic. Novosibirsk, Izd. Sib. Otd. Ross. Akad. Nauk]: 114-118. / Indusiella thianschanica, Crossidium squamigerum, Physcomitrium sphaericum, Arnellia fennica, Riccia frostii.

[SHKHAGAPSOEV, S.H.] ШХАГАПСОЕВ, C.Х. 2000. Моховидные. - [Bryophytes] В кн.: Красная книга Кабардино-Балкарской Республики. Нальчик, “Эль$\Phi a$ " [In: Red book of Kabardino-Balkar Republic. Nalchik, Ael'-Fa]: 298. / Sphagnum palustre.

[VOLOSNOVA, L.Ph. \& al. (see below)] ВОЛОСНОВA, Л. Ф. и др (см. ниже). 2003. Мохообразные. [Bryophyta] В кн.: Красная книга Рязанской области. Рязань, "Узорочье" [In: Red book of Ryazan 
Province. Ryazan, Uzoroch'e]: 27-36. / [Volosnova, L.Ph.] Волоснова, Л. Ф.: Fissidens osmundoides, Fontinalis hypnoides, Ephemerum serratum; [Volosnova, L.Ph. \& M. S. Ignatov] Волоснова, Л. Ф., М. С. Игнатов: Anomodon longifolius, $A$. attenuatus, Dicranum viride, Leucodon sciuroides, Neckera pennata, Plagiothecium latebricola, Sphagnum obtusum.

[ZYKOV, I.V. \& A.A. NOTOV, U.N. SPIRINA] ЗЫКОВ, И.В., А.НОТОВ, У.Н. СПИРИНА 2002. Отдел Мохообразные - Bryophyta. - [Divisio Bryophytes Bryophyta] В кн.: Красная книга Тверской области . Тверь, Вече Твери и АНТЭК [In: Red Data Book of the Tver' Province. Tver', Veche Tveri \& ANTEK]: 1035. Hamatocaulis vernicosus, Calliergon richardsonii, Limprichtia cossonii, Pseudocalliergon lycopodioides, Scorpidium scorpioides, Tomentypnum nitens, Anomodon longifolius, A. viticulosus, A. attenuatus, Isothecium alopecuroides, Bryum schleicheri, Helodium blandowii, Palustriella commutata, Racomitrium microcarpon, $R$. heterostichum, R. canescens, Dicranum bergeri, $D$. bonjeanii, D. viride, D. fragilifolium, Paraleucobryum longifolium, Meesia triquetra, Paludella squarrosa, Myrinia pulvinata, Homalia trichomanoides, Neckera pennata, Orthotrichum anomalum, O.pallens, O. pumilum, Ulota crispa, Plagiothecium latebricola, Atrichum angustatum, Aloina rigida, Gyroweisia tenuis, Pterygoneurum ovatum, Seligeria pusilla, S. campylopoda, Splachnum ampullaceum, S. rubrum, Sphagnum palustre, S. pulchrum, S. lindbergii, Dichelyma falcatum, Encalypta vulgaris, E. streptocarpa, Riccardia palmata, R. latifrons, Bazzania trilobata, Kurzia pauciflora, Metzgeria furcata, Porella platyphylla, Nowellia curvifolia, Odontoschisma denudatum, Frullania dilatata, Nardia insecta. 